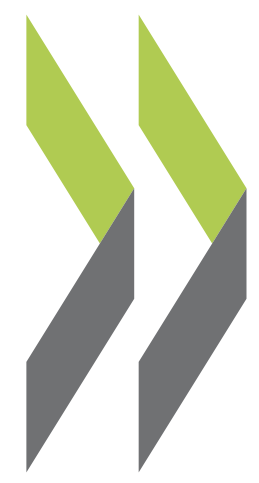

OECD Economics Department Working Papers No. 1017

\author{
Investing Efficiently \\ in Education and Active \\ Labour Market Policies \\ in Slovakia
}

\title{
Caroline Klein
}

https://dx.doi.org/10.1787/5k4c9kvmv3g4-en 
Organisation de Coopération et de Développement Économiques

Organisation for Economic Co-operation and Development

ECONOMICS DEPARTMENT

English - Or. English

INVESTING EFFICIENTLY IN EDUCATION AND ACTIVE LABOUR MARKET POLICIES IN SLOVAKIA

ECONOMICS DEPARTMENT WORKING PAPERS No. 1017

By Caroline Klein

All OECD Economics Department Working Papers are available through OECD's Internet website at http://www.oecd.org/eco/Workingpapers

JT03333722

Complete document available on OLIS in its original format

This document and any map included herein are without prejudice to the status of or sovereignty over any territory, to the delimitation of international frontiers and boundaries and to the name of any territory, city or area. 


\section{ABSTRACT/ RÉSUMÉ \\ Investing efficiently in education and active labour market policies in Slovakia}

In Slovakia, educational outcomes are below the OECD average and are too dependent on the socioeconomic background of students. Unemployment is high and the school-to-job transition process does not work well. Spending on education and active labour market policies are very low by international standards. While reforms are under way in both areas, further efforts are needed to support the domestic drivers of growth. At a time of fiscal consolidation, these two policy areas should at the least be protected from budgetary cuts while every opportunity for efficiency gains should be seized. Not least because of the high level of long-term unemployment, more emphasis should be placed on activation policies, particularly on placement services, which are currently underfinanced but also insufficiently evaluated. Educational achievements and thus future labour market outcomes could be improved by re-allocating resources to teaching activities, in particular for disadvantaged pupils. Developing work-based vocational education would also facilitate the transition from school to work.

This Working Paper relates to the 2012 OECD Economic Survey of the Slovak Republic (www.oecd.org/eco/surveys/slovakia2012).

JEL classification: H52, I21, I28, J21, J24, J64, J68

Keywords: Slovakia, unemployment, education, labour market policies, vocational training, lifelong learning

\section{Investir efficacement dans l'éducation et dans les politiques actives du marché du travail en Slovaquie}

En Slovaquie, les résultats scolaires sont inférieurs à la moyenne de l'OCDE et sont trop tributaires de l'origine socio-économique des élèves. Le taux de chômage est élevé et le processus de transition de l'école à la vie active ne fonctionne pas bien. Les dépenses d'éducation et de politiques actives du marché du travail sont très faibles par rapport aux normes internationales. Alors que des réformes sont en cours dans ces deux domaines, des efforts supplémentaires sont nécessaires pour soutenir les facteurs domestiques de croissance. Au moment de la consolidation budgétaire, ces deux domaines doivent au moins être protégés contre les coupes budgétaires alors que toutes les possibilités de gains d'efficacité doivent être saisies. Notamment en raison du niveau élevé de chômage de longue durée, l'accent devrait être mis sur les politiques d'activation, en particulier sur les services de placement, qui sont actuellement sous-financées, mais aussi insuffisamment évaluées. Les résultats scolaires et donc les futures performances sur le marché du travail pourraient être améliorés par la réaffectation des ressources aux activités d'enseignement, en particulier pour les élèves défavorisés. Le développement de la formation en milieu professionnel devrait également faciliter la transition de l'école à la vie active.

Ce Document de travail se rapporte à l'Étude économique de l'OCDE de la République slovaque 2012 (www.oecd.org/eco/etudes/slovaquie2012).

Classification JEL: H52, I21, I28, J21, J24, J64, J68

Mots clés: Slovaquie, chômage, éducation, politiques du marché du travail, formation professionnelle, formation continue

\section{(C) OECD (2013)}

You can copy, download or print OECD content for your own use, and you can include excerpts from OECD publications, databases and multimedia products in your own documents, presentations, blogs, websites and teaching materials, provided that suitable acknowledgment of OECD as source and copyright owner is given. All requests for commercial use and translation rights should be submitted to rights@oecd.org. 


\section{TABLE OF CONTENTS}

\section{INVESTING EFFICIENTLY IN EDUCATION AND ACTIVE LABOUR MARKET POLICIES IN}

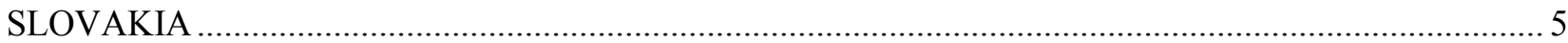

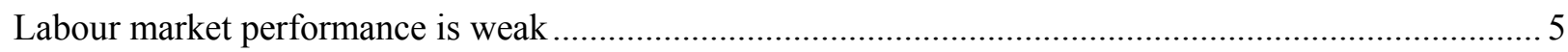

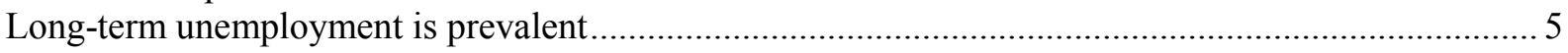

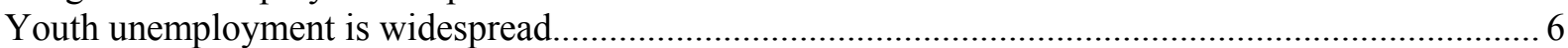

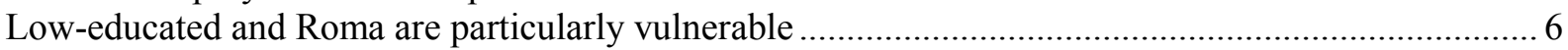

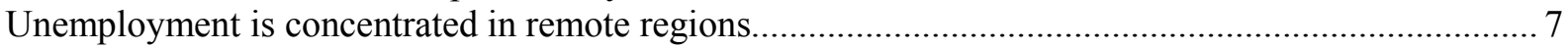

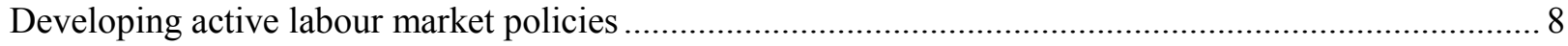

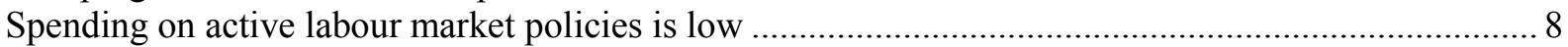

Programmes are insufficiently oriented towards labour market needs ............................................ 10

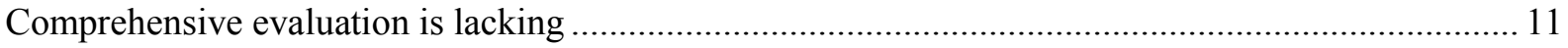

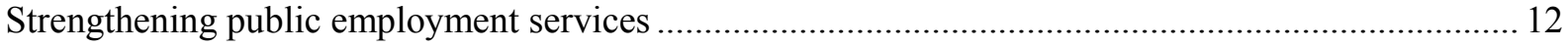

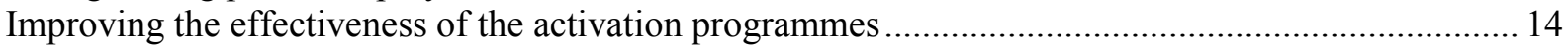

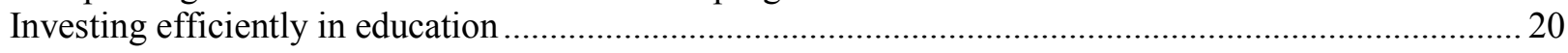

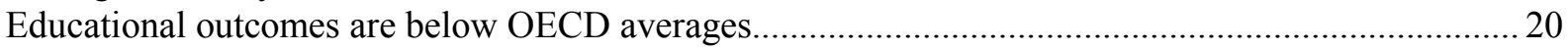

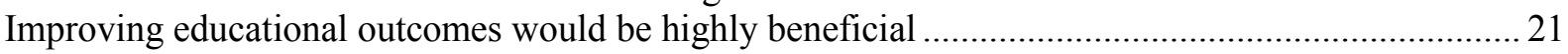

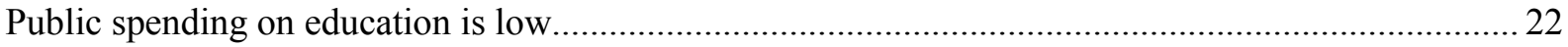

Achieving efficiency gains in the primary and secondary education systems ....................................2 23

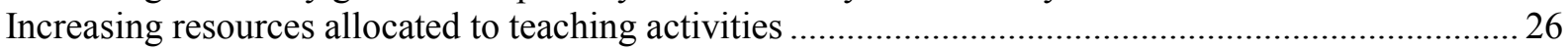

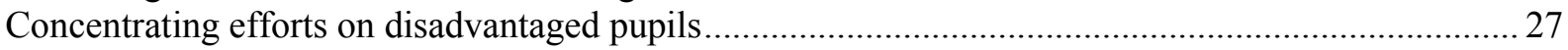

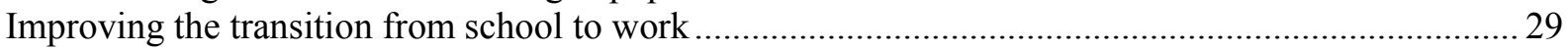

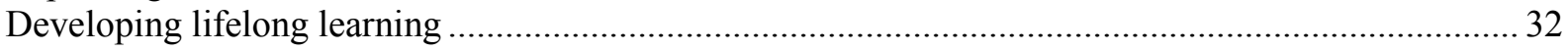

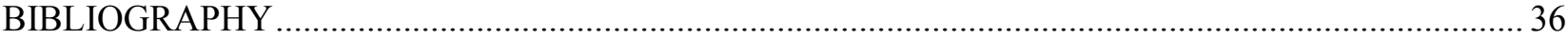

\section{Tables}

1. Employment rates and educational attainment, 2010

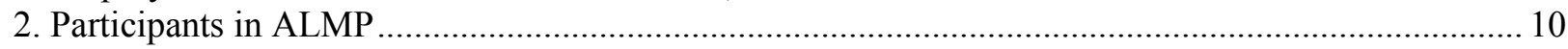

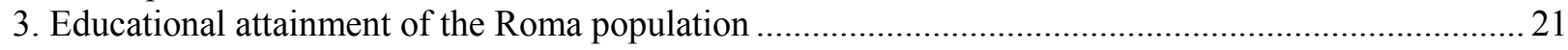

4. Unemployment rate by educational attainment level ..................................................................... 29

\section{Figures}

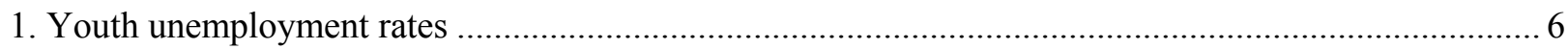

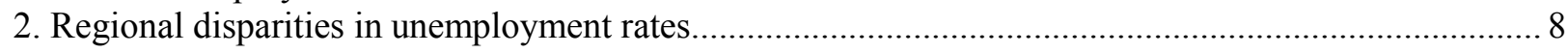

3. Spending on and participation in ALMPs by level of unemployment ……..................................... 9

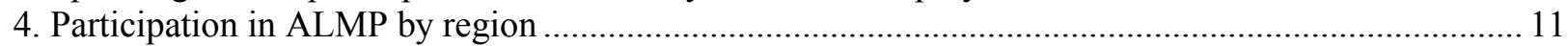

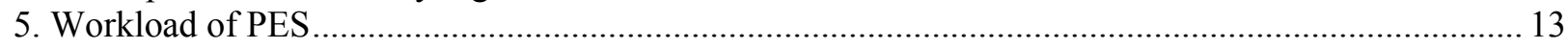

6. Participants in start-up incentives by educational level, age and region ............................................ 15

7. Participation in direct job creation and training programmes .......................................................... 17

8. Educational level, average Pisa score and impact of the socio-economic background.........................2 21

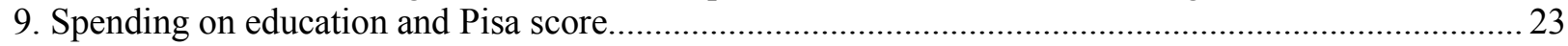


10. Average class size and student-teacher ratio in primary and secondary education ...........................25

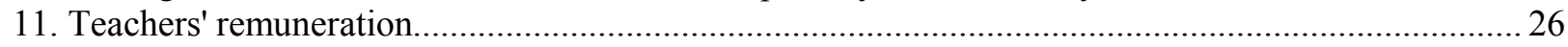

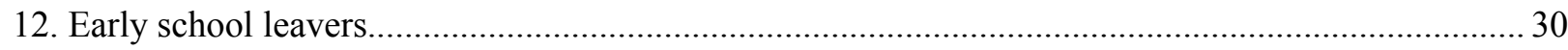

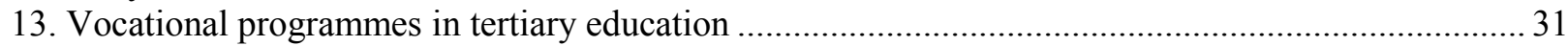

\section{Boxes}

Box 1. Recommendations for improving active labour market policies ............................................. 20

Box 2. Policy initiatives to raise educational outcomes of the Roma population ................................... 28

Box 3. Introducing an effective apprenticeship system........................................................................ 31

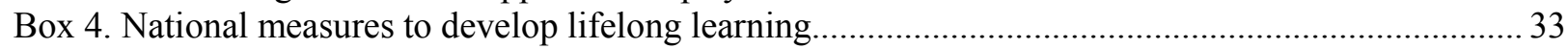

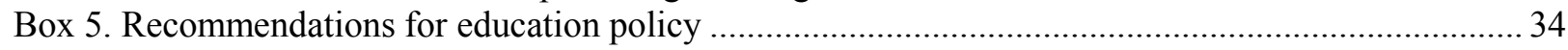


ECO/WKP(2013)9

\title{
INVESTING EFFICIENTLY IN EDUCATION AND ACTIVE LABOUR MARKET POLICIES IN SLOVAKIA
}

\author{
Caroline Klein ${ }^{1}$
}

Improving the labour market outcomes is crucial to facilitate fiscal consolidation, boost long-term growth and reduce existing inequalities, thereby fostering sustainable growth and improving social cohesion. Growth in Slovakia is held back by a high and persistent level of structural unemployment, worsened by large pockets of underperformance. Long-term unemployment increased in the aftermath of the crisis to record levels, youth unemployment is among the highest in the OECD and the Roma minority is largely excluded from the labour market. Innovative capacities are also low by international comparison, hampering job creation in domestic firms (OECD, 2010b). Eliminating these hurdles to higher growth would considerably facilitate fiscal consolidation and improve the sustainability of public finances (OECD, 2012c). Increasing employment rates would extend the fiscal base, reduce benefit dependency, and limit public costs related to social exclusion.

Reforming the education system and stepping up active labour market policies would help to improve labour market outcomes. The school-to-work transition is weak and the education system is not responding to labour market needs. Increasing the quality of education would significantly boost growth but few resources are currently allocated to schools and teachers to improve outcomes. Similarly, while well-designed active labour market policies could contribute to reducing long-term unemployment and increasing the employability of disadvantaged job seekers, such measures are currently underdeveloped. In times of consolidation, resources are limited requiring careful prioritisation of spending and ensuring the cost efficiency of implemented measures. This chapter presents some options for phasing out existing inefficiencies while further developing education and labour market policies.

\section{Labour market performance is weak}

\section{Long-term unemployment is prevalent}

The unemployment rate is the fifth highest in the OECD and is set to remain high in the coming years. With a share of long-term unemployed at around $64 \%$ of jobseekers, almost twice the OECD average, the incidence of long-term unemployment was among the largest in the OECD in 2011 and is expected to increase further because of hysteresis effects. Furthermore, matching frictions have developed, with a job filling rate (ratio between the number of hiring and the average stock of unfilled vacancies) below its precrisis level (OECD, 2012a).

1. Caroline Klein was Acting Head of the Slovakia Desk in the Economics Department of the OECD. This paper was originally published as part of the 2012 Economic Survey of Slovakia (OECD, 2012c).The author would like to thank Andreas Wörgötter, Robert Ford, Andrew Dean, Lilas Demmou, Malgorzata Kuczera, Claire Shewbridge, Andrea Bassanini, and David Grubb for their useful comments. The paper benefitted from consultancy work by Gabriel Machlica, Štefan Kišš, and Matej Šiškovič and from discussions with Slovak government officials and researchers. Statistical assistance was provided by Béatrice Guérard and Seung-Hee Koh and technical preparation by Pascal Halim. 


\section{Youth unemployment is widespread}

As in past recessions, the prospects of the youth have significantly deteriorated in the wake of the crisis. The unemployment rate among young people aged 15-24 increased by almost 15 percentage points between 2008 and 2010, more than three times as much as for adults. Also, as job opportunities have been scarce during the recovery, youth have difficulties to find their way into work. As a result, the youth unemployment rate in Slovakia was the third highest in the OECD in 2011 (33\%) and exceeded twice the national rate. The risk of being unemployed for youth compared to adults is higher in Slovakia than in the OECD on average, with a relatively large youth/adult unemployment ratio (Figure 1, upper panel). The spell of unemployment for youth is also high by international comparison. $50 \%$ of youth unemployed are long term unemployed while the incidence of long term unemployment for youth stands at $21 \%$ in the OECD.

Figure 1. Youth unemployment rates
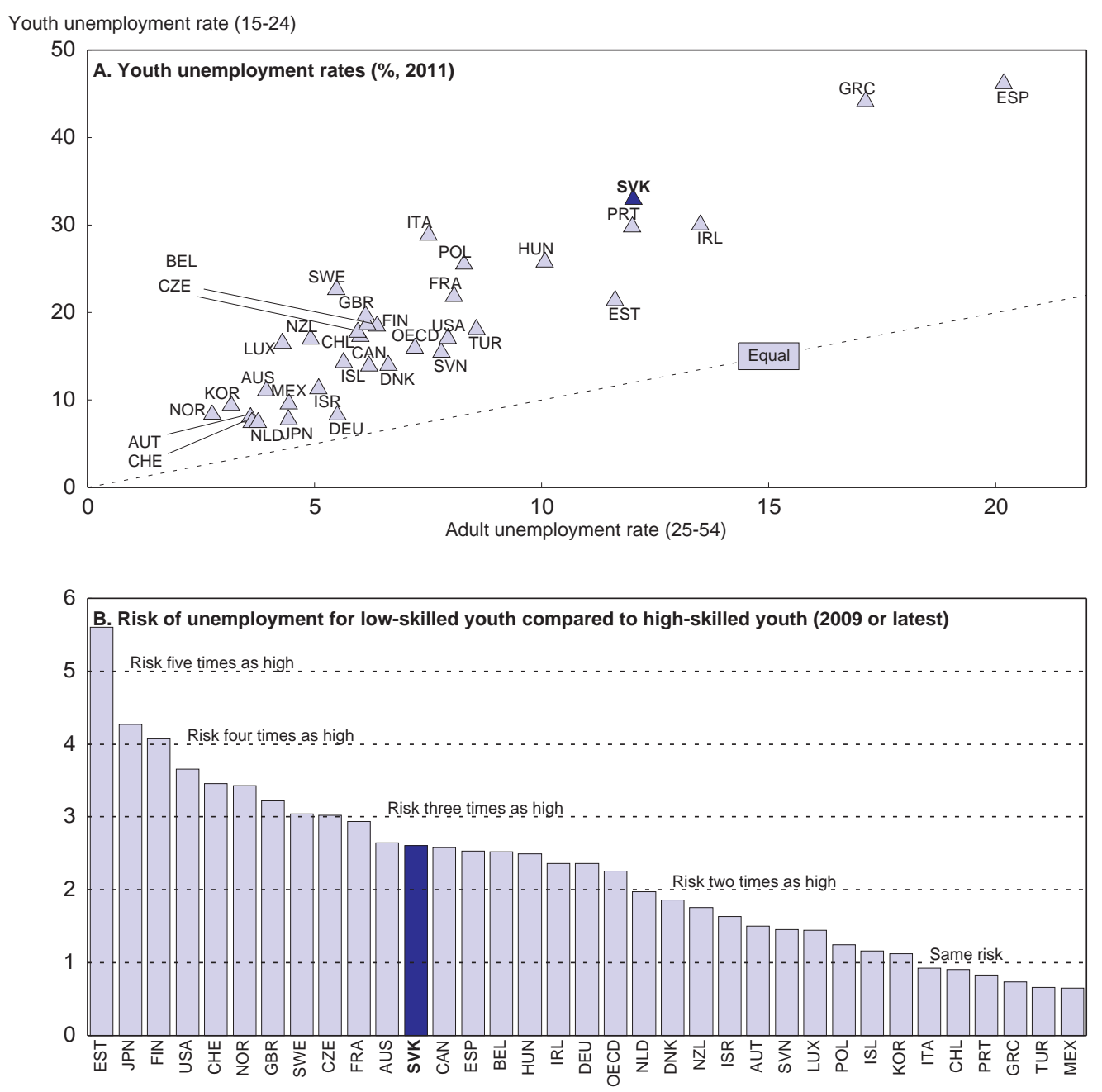

Source: OECD, Labour Force Statistics database and Scoreboard for youth aged 15-24.

\section{Low-educated and Roma are particularly vulnerable}

Labour market performance is strongly linked with the level of education. The employment rate of the low educated (below upper secondary education) was only half the OECD average in 2010 while the 
employment rate for tertiary educated was not significantly different (Table 1). The lack of qualification considerably increases the probability of being unemployed, especially for the young generation. In 2010, the low-skilled youth (without an upper secondary education) had a risk of being unemployed more than double the high-skilled youth (with a tertiary education) (Figure 1, lower panel). Overall, around 60\% of the unemployed are low skilled.

Table 1 Employment rates and educational attainment, 2010

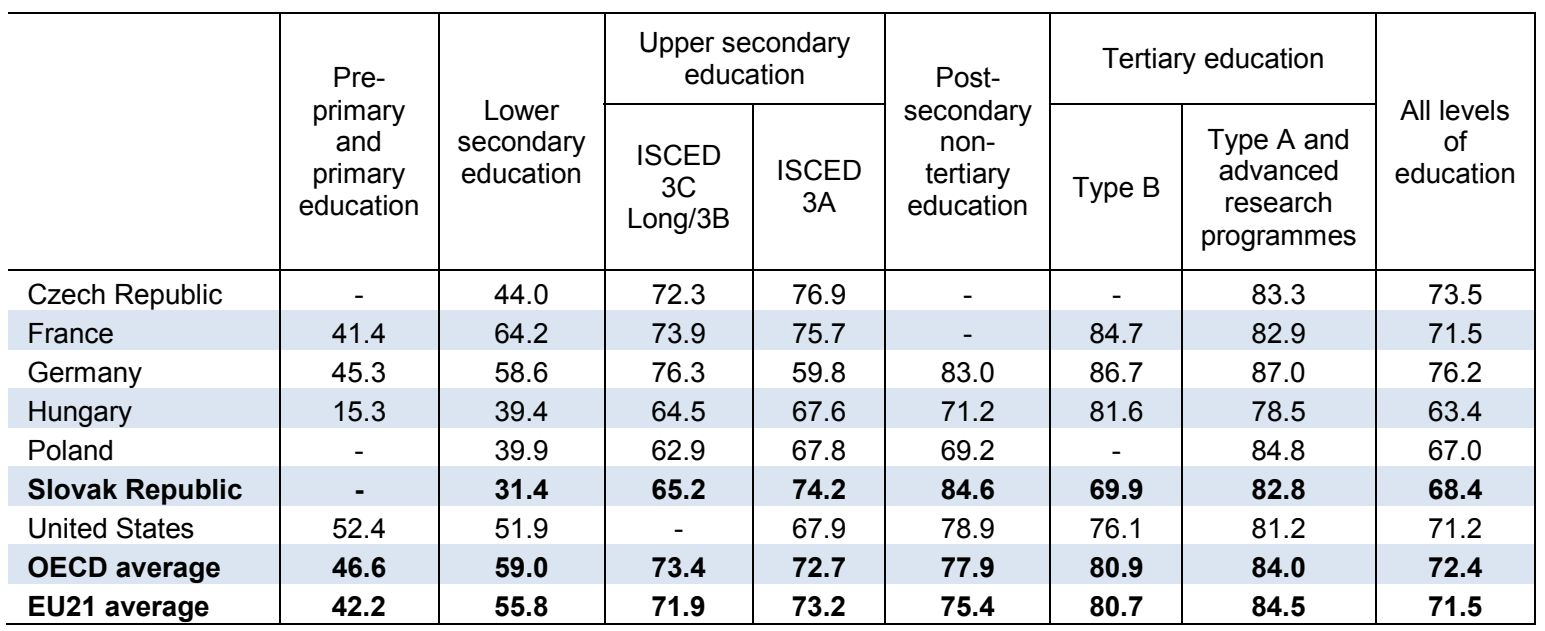

Note: Number of 25-64 year-olds in employment as a percentage of the population aged 25 to 64 , by level of education attained. Source: Education at a Glance 2012, table A7.1b.

Roma are also particularly disadvantaged on the labour market, with an unemployment rate above $73 \%$ (UNDP, 2012). Their educational outcomes are relatively poor: around $70 \%$ of the Roma population have less than upper secondary education ( $v s$. less than $10 \%$ of the total population). However, their low level of education only partly explains their labour market outcomes. At the same level of education, the unemployment rate of Roma is between two to eight times higher than for non-Roma living in the same region. A limited access to job opportunities due to remote settlement structures and discrimination on the labour market are playing a great role in the social exclusion of the Roma population (World Bank, 2012a). Data on Roma are scarce but estimates tend to show that Roma account for a large and increasing share of the unemployed labour force in Slovakia. According to a World Bank study, Roma account for more than $13 \%$ of new labour market entrants (World Bank, 2012b). As a consequence, the cost of non-inclusion of Roma induced by higher spending on social assistance and tax revenues losses is significant: the fiscal gap is estimated at around 3\% of government spending (World Bank, 2012b). Marcinčin and Marcinčinová (2009) estimate that the total economic cost of Roma non-inclusion amounts to $8 \%$ of GDP.

\section{Unemployment is concentrated in remote regions}

Regional disparities in unemployment are among the highest in the OECD (Figure 2, left panel). The unemployment rate in the highest-unemployment regions (Banská Bystrica and Presov) was more than three times that in the lowest-unemployment region (Bratislava) in 2010. This reflects low labour mobility, hampering labour market adjustments at the national level (Paci et al., 2007). Low-skilled unemployment is more prevalent in regions with a high share of unemployment (Figure 2, right panel). This is partly due to the low availability of affordable housing in dynamic regions. The rental housing market is under-developed, undermining the mobility notably of low-paid workers whose wage gains from moving to take up work may not sufficiently exceed the additional housing costs (OECD, 2009b). 
Figure 2. Regional disparities in unemployment rates

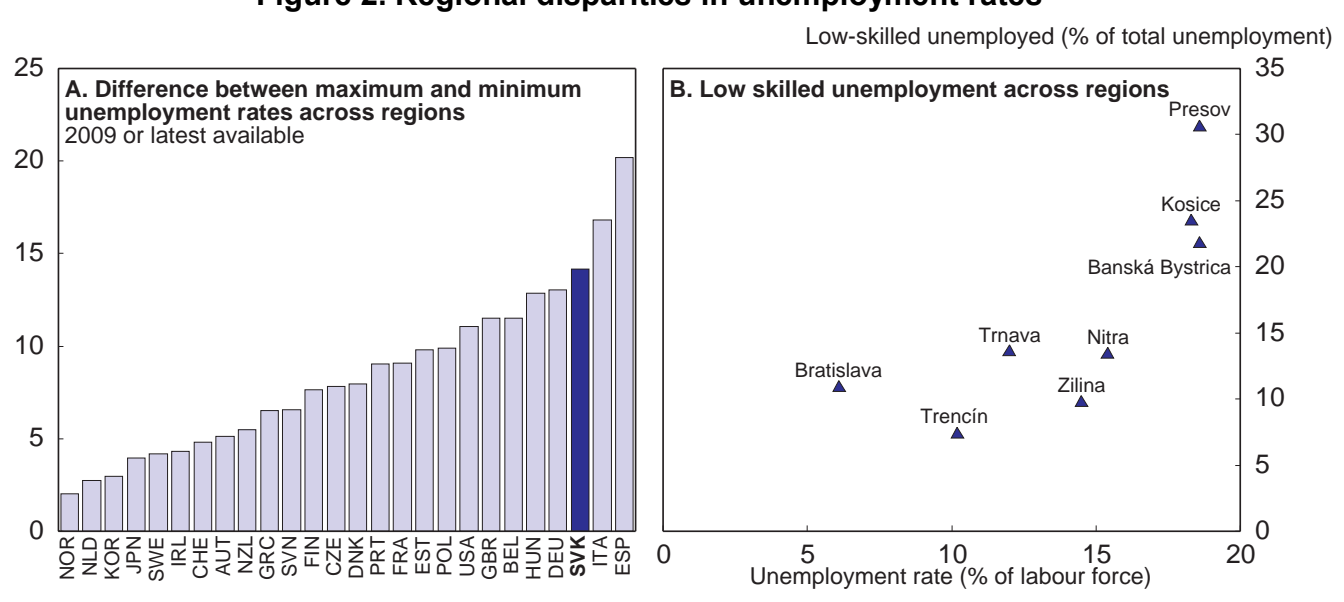

Source: OECD Regional database and Central Labour Office.

\section{Developing active labour market policies}

\section{Spending on active labour market policies is low}

High unemployment and the increasing exclusion of at-risks groups from employment require strong activation policies to minimize the increase in structural unemployment. Efficient active labour market policies can also contribute to reducing under-employment and stimulate potential growth by ensuring a better use of the labour force through better matching, improved mobility, and co-operation with potential employers. Particular attention should be devoted to reduce youth, low skilled and Roma inactivity and unemployment as they constitute persistent pockets of underperformance in the labour market.

Slovakia's spending on active labour market policies (ALMP) is one of the lowest in the OECD. In 2010 , it accounted for only $0.3 \%$ of GDP, less than half the OECD average ( $0.7 \%$ of GDP). This is mainly due to a low level of spending per participant, but a relatively low participation of the unemployed also plays a role (Figure 3, lower panel). ${ }^{2}$

2. Data are from the OECD Labour Market Programme database. Data often include training allowances, wages or other forms of income support paid to programme participants. Slovak data include some types of income support payment but not the "activation allowance" or regular social benefits that are paid to ALMP participants in some cases. The "activation allowance" has a clear activation purpose as it is offered to jobseekers participating in job creation programmes (small municipal works) and thus could be considered as an active labour market measure. Spending on activation allowance amounted to around EUR 10 million in 2009, 6\% of total ALMP and 0.02\% of GDP. Including such spending in the database is not changing significantly the figures presented in the chapter. The other regular social benefits are not conditioned to work availability or to participation in ALMP (contrary to most other OECD countries) and thus are not considered here as spending on ALMP. 
Figure 3. Spending on and participation in ALMPs by level of unemployment
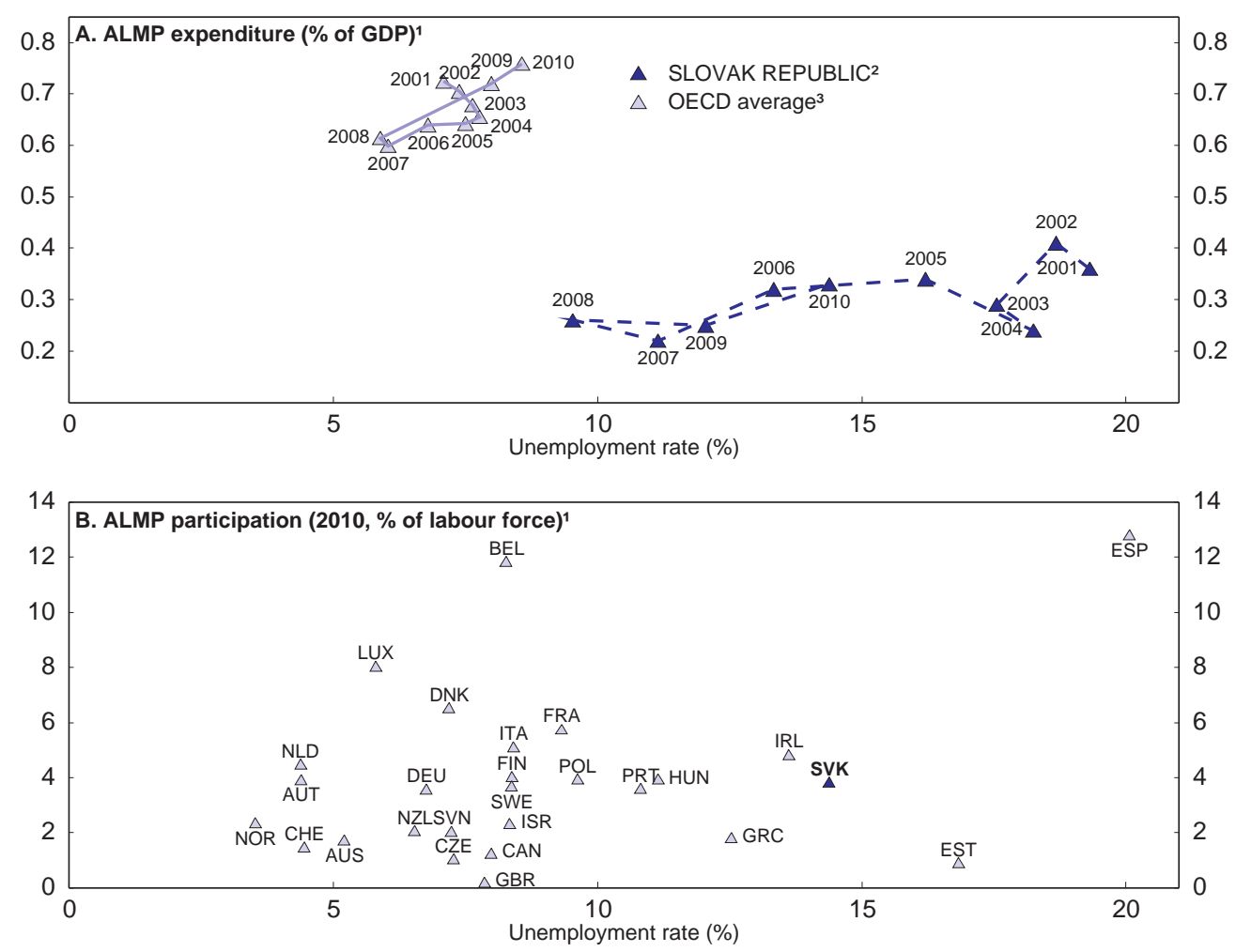

1. The ALMP expenditure total shown includes the category "Public Employment Service and administration", whereas the ALMP participant total does not include this category.

2. Data for other OECD countries often include training allowances, wages or other forms of income support paid to programme participants: Slovak data include some types of income support payment but not the "activation allowance" or regular social benefits that are paid to ALMP participants in some cases (see main text).

3. OECD average is computed as unweighted average for expenditure in ALMP and for the unemployment rate. Country coverage is based on continuity and availability over the time period; it excludes Chile, Estonia, Greece, Hungary, Iceland, Israel, Italy, Japan, Luxembourg, Norway, Slovenia, Switzerland, Turkey, and the United Kingdom.

Source: OECD Economic Outlook database and OECD, Labour Market Programme database.

Spending on ALMP has been very volatile in the last years and has not reflected labour market developments. While in the average OECD country the expenditure on ALMP is positively correlated with the unemployment rate, this is not so for Slovakia (Figure 3, upper panel). In particular, during the crisis ALMP were implemented with some delays. While most other OECD countries increased their expenditures in response to the crisis in 2009, spending on ALMP increased only from 2010 onwards in Slovakia. Furthermore, despite a strong increase in $2010(+38 \%)$, the additional spending on active labour market programmes in response to the crisis - as reported in the OECD database - was only about half the OECD average (OECD, 2010b).

ALMPs are mainly financed through EU funds (51\% in 2011). This partly explains the low reactivity of ALMP to labour market developments. The absorption of EU funds induces some burdensome procedures creating delays between the conception and the implementation of a measure. In addition, budget planning has been weak, in particular regarding the capacity to use EU resources. Mandatory measures (according to law) receive funding priority. As a result, if the budget for these measures is insufficient, for instance because EU funds were not used or budget planning was inappropriate, funds initially allocated to non-mandatory measures (e.g. training) are used to finance mandatory measures, thus 
limiting the implementation of non-mandatory programmes. Expenditure planning should be improved to ensure that spending on ALMP adequately reflects the labour market needs. Also, the absorption of EU funds should be increased by reforming the system of funds management and reducing the administrative hurdles to the submission and the selection of projects as recommended in the last Surveys (OECD, 2010b; OECD, 2012c).

The low level of spending on ALMPs may relate to the fact that the unemployed are insufficiently encouraged to participate in programmes. The eligibility for the unemployment insurance benefit is very strict and the benefit is of short duration (Venn, 2012). As a consequence, only around $10 \%$ of the unemployed receive unemployment insurance benefits and are thus required to actively search for a job. Also, when meeting the eligibility criteria, the unemployed receive social assistance benefits. Entitlement to the basic amount of social assistance (benefit in material need) is not formally conditioned to work availability. Recipients with work ability who account for a large share of benefit recipients are not obliged to register in the labour office (World Bank, 2012a). If not registered, they are not directly informed about available vacancies and activation or training opportunities and progressively get detached from the labour market. Some incentives to register in labour offices exist as free health insurance is provided only to registered unemployed. Nevertheless, participation in ALMP and job search activities of social assistance recipients with some work ability should be fostered further by, at least, obliging them to register as jobseekers and to participate in activation measures. The local labour offices should take particular attention to maintaining the link between social assistance recipients and the labour market.

\section{Programmes are insufficiently oriented towards labour market needs}

According to law, ALMP should be targeted to "disadvantaged jobseekers", but the definition of a disadvantaged jobseeker is very broad. ${ }^{3}$ It includes notably the long term unemployed, the older and disabled jobseekers and the school graduates without a regular job two years after graduation. These groups account for around $80 \%$ of the registered unemployed. Nevertheless, disadvantaged job seekers are under-represented in certain programmes, including the largest one: in the start-up incentives programme which accounts for around $40 \%$ of the ALMP budget for programmes (excluding public employment service), disadvantaged job seekers account for only $42 \%$ of participants ( $v s$. at least $80 \%$ in total unemployment). Overall, participation of at-risk jobseekers in ALMP is quite low (Table 2). In particular, $40 \%$ of ALMP participants are low-skilled while they account for $60 \%$ of the unemployed and have higher risks of being excluded permanently from the labour market.

Table 2. Participants in ALMP

\begin{tabular}{llrr}
\cline { 2 - 4 } & \multicolumn{1}{c}{$\begin{array}{c}\text { Share among ALMP } \\
\text { participants }\end{array}$} & $\begin{array}{c}\text { Share in total } \\
\text { unemployment }\end{array}$ \\
\cline { 2 - 4 } & Youth (aged $<25)$ & 16 & 21 \\
Low skilled & 40 & 60 \\
Long term unemployed & 55 & 60 \\
\hline Source: Central Labour Office & & &
\end{tabular}

The share of the ALMP participants among job seekers is significantly lower in regions with higher unemployment rates. While $12 \%$ of the unemployed were participating in programmes on average in 2010 ,

3. According to the Article $\S 8$ of the Act on Employment Services, the disadvantaged jobseekers include notably: young graduates under 25 years of age who completed full-time vocational training during the past two years and has not found a first paid regular employment; older jobseekers aged more than 50 years; the long-term unemployed registered at the employment services for at least 12 months over the past 16 months; person with health problems; migrants within the European Union; people who have not completed secondary school. 
this rate reached around $25 \%$ in Bratislava region and $10 \%$ in the eastern regions. This partly reflects the low participation rate of low-skilled and long-term unemployed in the programmes (Figure 4).

Figure 4. Participation in ALMP by region

2010

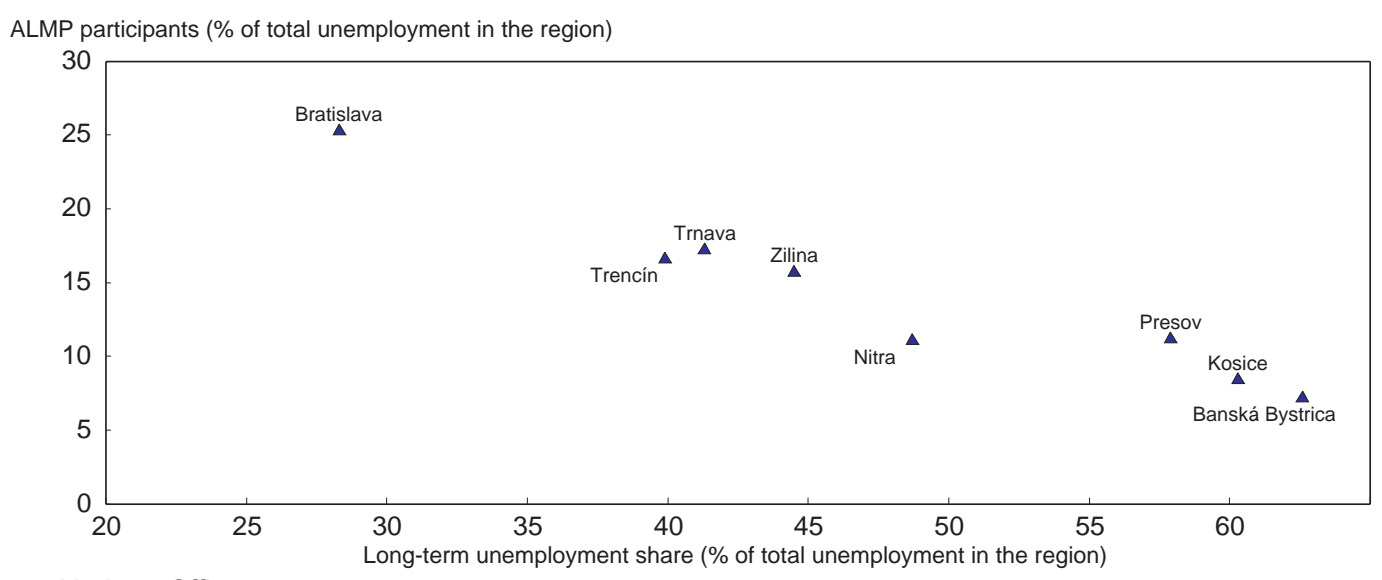

Source: Central Labour Office.

The low participation of disadvantaged jobseekers in ALPMs may be due to the fact that out of 29 programmes only nine are targeted to a specific group (one to the youth, one to social benefit recipients and seven to disabled jobseekers). Targeting of ALMP should be improved and programmes should be made more client-oriented to effectively support the more in-need groups. Doing so would require identifying the pockets of underperformance and further analysing the labour market outcomes of at-risk groups. Such information is important for designing the programmes in a client-oriented manner and is lacking in Slovakia. Setting specific performance targets regarding disadvantaged groups could also help to prioritize policy actions and induce efficiency gains (OECD, 2012c). For instance, youth became a specific target for labour market policies in Japan in 2000 and the reorientation of policy appears to have had a significant positive impact as the unemployment rate of this group declined by $20 \%$ in four years (Duell, 2010b). The performance targets could be defined at the local level to better reflect the local labour market issues and elaborated by a close cooperation between the central and local authorities and the local labour offices.

\section{Comprehensive evaluation is lacking}

ALMP are not deeply enough evaluated and their impact on the labour market outcomes remains unclear. The few available evaluations point to their low effectiveness (e.g. Harvan, 2010; Vagac, 2010) as well as low participation in some programmes. Among the 29 existing programmes in 2011, only 22 were used and only 12 have more than 1000 participants (World Bank, 2012a). In 2011, a few programmes have been phased out due to their low rate of use. However, the reasons behind their lack of success were not investigated. Because of the lack of monitoring, inefficient programmes may continue to operate. While the low level of spending on ALMP suggests more resources should be allocated in this area, spending on these programmes should only be increased after a proper evaluation of their impact has been made available. Also, as financial resources are scarce, new programmes could be tested with pilot projects before being implemented at the national level.

Data on programme outcomes are lacking. Evaluation of active labour market measures is currently undertaken semi-annually and only two indicators are systematically used (the number of participants and the cost of the programmes). The central labour office provides some indicators on the labour market position of participants after the termination of some specific programmes but without detailed information 
on the participants themselves (necessary to estimate the effectiveness of these programmes and to correct the selection biases). Data gathering is administratively burdensome and decentralized (done by the regional labour offices). A comprehensive analysis of ALMP requires harmonizing and extending data collection. Measures going in this direction have been designed. The planned data collection and systematic evaluation of ALMP should be implemented urgently while making sure that all necessary technical elements are in place. In particular, to assess the net effect of programmes on the labour market and on public finances, employment and income of the ALMP participants should be tracked, for instance by matching benefit, tax and social insurance databases (OECD, 2005a).

\section{Strengthening public employment services}

The Public Employment Service (PES) has a key role to play in reducing unemployment. Empirical evidence suggests that services provided by PES, such as job search assistance and counselling, have the largest positive impact on labour market outcomes (OECD, 2005a; Kluve, 2010). Regular reporting creates opportunities for the PES to encourage job search and to share up-to date information on vacancies. Even when employment opportunities are scarce, contact with PES helps to retain labour market attachment, can damp the hysteresis effects, and thus limit the built of long-term unemployment (OECD, 2010f).

Spending on PES did not adapt to the greater demand created by the increase in unemployment. The rise in PES staff in response to the crisis was half the OECD average while the increase in registered jobseekers was 5 percentage points stronger (OECD, 2010f). Also, as part of fiscal consolidation measures, the number of staff was cut significantly in 2011 while the number of registered unemployed kept rising. As a result, the workload of PES staff has been increasingly large, which hampers the provision of high quality, targeted and individualized services. The caseload, estimated by the number of registered job seekers per front line local staff, has more than doubled since 2006 (Figure 5). In 2010, a front line local office staff worker had to deal with around 410 jobseekers. It is almost three times more than in France and eight times more than in Germany (Hespel et al., 2011). In addition, the caseload varies significantly across regions, suggesting that resources are not adequately distributed across local labour offices (Nádaždyová, 2011).

Slovakia has rightly introduced a profiling system of jobseekers and has implemented detailed registration interviews followed by regular reporting. Such initiatives, including the introduction of Individual Action Plans, are not bearing fruit due to limited capacities in PES. A relatively low share of resources is dedicated to placement and ALMP-related services (around 50\%). In Switzerland, placement services and ALMP account for $66 \%$ of resources, and this ratio reaches around $80 \%$ in Norway and Luxemburg (Duell et al., 2010a).

In view of the level of unemployment and the increase in long term unemployment, more resources should be allocated to the PES. Also developing the accountability of public administration for instance by extending the use of performance assessment in financing, contract renewals and staff remuneration from current low level could help to achieve efficiency gains (OECD, 2012c). These changes could be inspired by successful international experience. As an example, the German PES achieved large efficiency gains with the 2005 Hartz IV reform, by improving cooperation between services in charge of active and passive labour market policies, reducing the caseload per PES staff and developing the results-based accountability of local employment agencies (Jacobi and Kluve, 2006). 
ECO/WKP(2013)9

Figure 5. Workload of PES

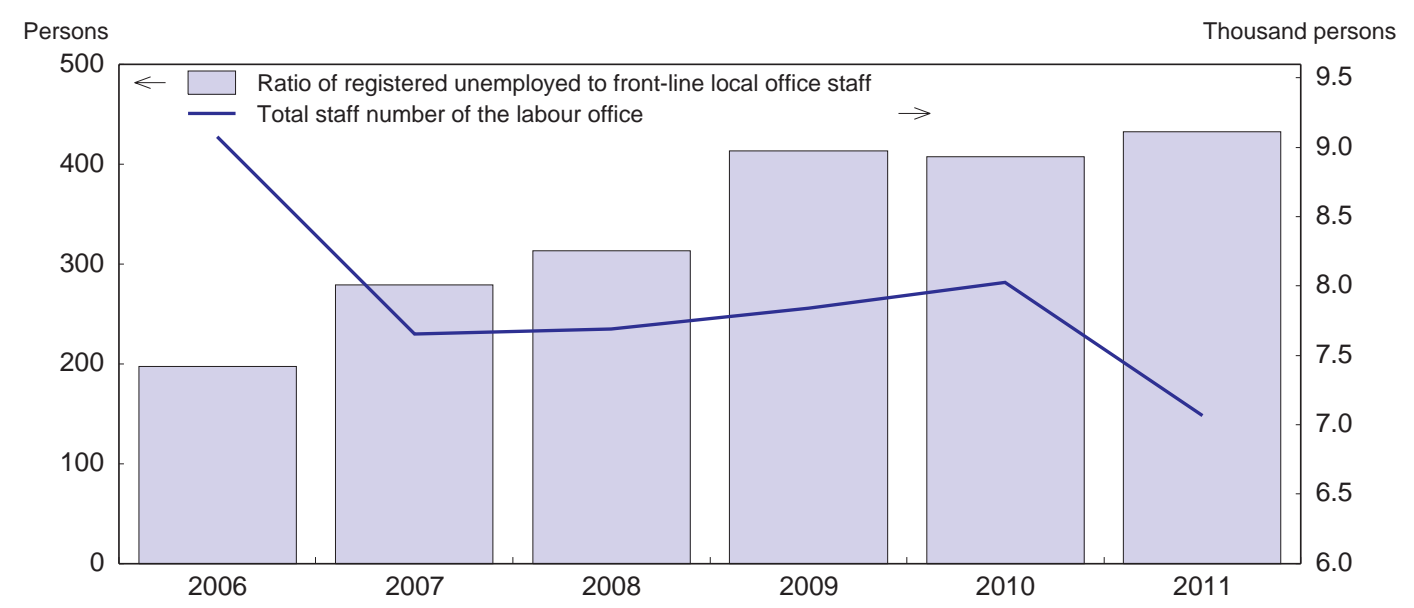

Source: Central Labour Office.

The local labour offices in charge of the placement services and the implementation of ALMP also administer social assistance benefits and public social support. Placement and social services are not cooperating, inducing work duplication and inefficiencies. For instance, as mentioned above, social benefit recipients with work ability are not in touch with placement services, as registration in the PES is not compulsory and services are formally separated. Efficiency gains could be made by creating one stop shops for jobseekers as initially planned when the two services were merged in 2004.

PES employees are also in charge of registering vacancies and collecting information on labour market developments. The labour offices are the main sources of information for jobseekers: almost $80 \%$ unemployed consider contacting the labour offices to seek for a job compared to $56 \%$ in the EU. At the same time, the number of reported vacancies by the labour offices has significantly decreased over time, not least due to the 2004 reform regarding the registration of vacancies (Kaluzna, 2008). Before 2004, employers were obliged to notify vacancies to the local labour office. Since 2004, the labour offices are responsible for the collection of job offers. This reform led to a significant reduction of communication between the labour offices and employers and to less information about local labour demand (Hanzelova and Kostolna, 2006). As a consequence, registered vacancies as a share of employment dropped from $10 \%$ to $4 \%$ between 2003 and 2004 . The number of unfilled vacancies reported by the labour offices was almost half the number of those reported by the Statistical office in 2011.

Improving the information of the PES on vacancies is crucial as it facilitates the placement of jobseekers but would also improve the matching of demand and supply in activation programmes. The registration of vacancies should thus be strengthened both quantitatively and qualitatively and more resources should be allocated to collect information on labour market developments. The collection method could also be changed to lighten the workload of PES employees. Around $65 \%$ of vacancies in 2010 were collected through personal, mail and telephone contacts (Central Labour Office, 2011). As in many OECD countries, effective online collection of job offers should be established, for instance by encouraging employers to publish vacancies online on a dedicated website. The Finnish PES has actively promoted the use of the online services both for employers and job seekers, resulting in a reduction of PES intervention in the screening and the matching of job seekers to vacancies (Duell et al., 2009). In Ireland, the introduction of the National Contact Centre is considered to have played a crucial role in doubling the number of registered vacancies since 2000 (Grubb et al., 2009). 
ECO/WKP(2013)9

\section{Improving the effectiveness of the activation programmes}

\section{Better targeting start-up incentives}

Start-up incentives consist in one-off subsidies allocated to the unemployed starting a business and are covered by two programmes in Slovakia: the contribution for self-employment and the contribution for self-employment to disabled citizens. A relatively large share of spending on ALMP is allocated to these measures. 30\% of ALMP participants were receiving start-up subsidies in 2010 ( $v s$. only $6 \%$ on average in the OECD). Spending on these programmes has continued to increase in recent years as the conditions for receiving the subsidies were temporarily widened in the wake of the crisis $(+15 \%$ between 2008 and 2010 , from EUR 35 million to 40 million). However, they increased less than the total spending on ALMP.

The effectiveness of these programmes is highly variable and available evidence tends to show that the net positive impact of these measures on employment is rather low (Martin and Grubb, 2001, Dar et al., 2009). These programmes are associated with high deadweight losses and displacement effects. While a proper evaluation measuring the effectiveness of the programme in Slovakia has not been carried out yet, it is likely that it induces large deadweight losses, because start-up incentives are not targeted and are not carefully monitored.

- The programme has wide eligibility criteria and is not enough monitored. The subsidy is provided to every jobseeker after 3 months of unemployment, providing a business plan and running a business for at least two years. In comparison, in Finland, the start-up grant is given in two periods, the second being conditional upon sufficient income and activities in accordance with the business plan. Such ex post monitoring could limit abuses with the unemployed benefiting from the subsidy without effectively running a business.

- The measure is not means tested and is not benefiting the most in-need groups. The participation of youth and long term unemployed is very low (13\% and $22 \%$ respectively in 2010 ) compared to their share in the total unemployment ( $21 \%$ and $60 \%$ respectively). Highly educated unemployed are over-represented; $20 \%$ of the new recipients had a tertiary education level versus only $7 \%$ among the unemployed in 2010 (Figure 6, upper panel). The measure is mainly used in regions with low levels of unemployment. In Bratislava, the economically most developed region, almost every fourth unemployed received the start-up benefit. By contrast, in the Kosice region, where unemployment is three times higher than in Bratislava, fewer than $5 \%$ of the unemployed used this programme (Figure 6, lower panel).

There were a several attempts to improve the effectiveness of the start-up incentives. In 2012, a draft amendment to the Act on Employment Services set stricter eligibility conditions by extending the mandatory period of time of running the business from two up to three years and by introducing the obligation to prove a positive tax income after the first year. It is unfortunate that this amendment was not passed. Eligibility criteria should be made stricter, for instance by means testing the provision of the allowance, while the monitoring of the measure should be strengthened. 
Figure 6. Participants in start-up incentives by educational level, age and region 2010 , in percentages
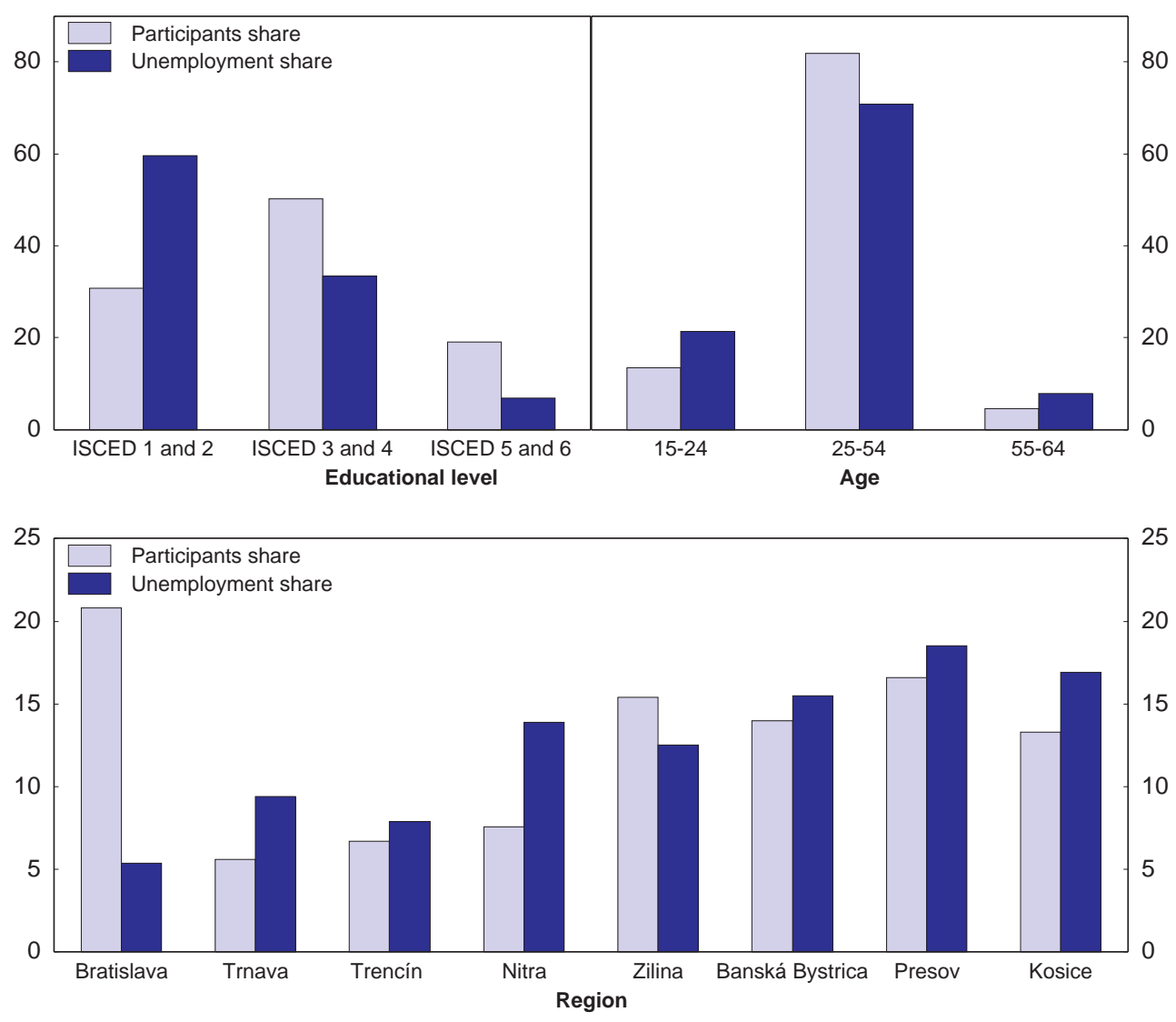

Note: The participant share is the share of a given group (i.e. 15-24 aged) in the total number of participants. The unemployment share is the share of a given group in total unemployment. For instance, $13 \%$ of participants and $22 \%$ of unemployed are aged $15-24$. Source: Central Labour Office; Statistical Office of the Slovak Republic, Regional database.

\section{Limiting the use of temporary activation works}

While direct job creation is among programmes with the worst outcomes (Kluve, 2010, Card et al., 2009), it is widely used in Slovakia. The participation rate in these programmes is very high by OECD standards (Figure 7, upper panel). One third of ALMP participants were involved in job creation measures in 2010. At the same time, spending on job creation measures is limited (only $4 \%$ of total spending on ALMP) but this is due to the fact that the allowance paid to a participant is not included in the data (see footnote $\mathrm{n}^{\circ} 2$ ). Direct job creation in Slovakia covers mainly community activation works (small municipal works) and contributions for voluntary service. Subsidies are allocated to municipalities and NGOs which provide part-time jobs (maximum 20 hours per week) to disadvantaged jobseekers (mainly social benefits recipients). Participants receive a lump sum benefit. These programmes last between 6 and 18 months and aim at broadening the skills and work routine of participants.

Empirical evidence suggests these programmes are not effective in reducing unemployment, as participants rarely get a permanent job in the regular market (Card et al., 2009). Harvan (2010) even finds that the community activation work programmes in Slovakia reduce the chances to get a job after programme completion. In 2010, only $4.4 \%$ of participants could find a job within 6 months after leaving the programme (World Bank, 2012a). International experiences suggest that the competences gained in 
these jobs are not relevant for private-sector jobs and lead to poor performance after the end of the programme (Duell et al., 2010a). In particular, the activation work programmes are not providing the skills and work experience that young people need to successfully integrate into the labour market and could lead to a long-term exclusion of schools leavers from employment (World Bank, 2012a). Direct job creation also induces lock-in effects by reducing the incentive to exit unemployment through job search or training.

In Slovakia, the risk is particularly high that the measures lock in participants in economically less developed regions given the low geographical labour mobility. As a result, these measures are likely to limit labour market adjustment and foster the persistence of regional disparities. Thus, job creation programmes should be proposed only when no other options are available, for instance for job seekers facing severe obstacles for employment as it provides at least some connection with the labour market. These programmes should not be allocated to early school leavers or young unemployed who have shown major difficulties in finding a job as these essentially need to acquire skills that would be transferable to private sector jobs and hence boost their employability (OECD, 2010a). The job creation programmes should at least be complemented by other activation measures, improving the employability of the participant and limiting lock-in effects. Participants should be encouraged to continue with job search and other assistance services. Also some financial benefits could be provided for activation work providers to engage the participants in training as suggested in OECD (2009a).

Other job creation programmes have been developed recently. Job creation measures in flood prevention and restoration of cultural heritage have been implemented since 2010. Contrary to community activation work, they lead to formal job contracts. While it is too early to assess their impact, these measures may help as they offer an outlook for real jobs to the participants. Nevertheless, these programmes should be carefully monitored. Also, additional EU funds (EUR 20 millions) will be allocated to finance community-based jobs in municipalities. The jobs created need to effectively increase the employability of participants by raising their qualifications and providing skills that are demanded in the private sector. 
Figure 7. Participation in direct job creation and training programmes

2010 , in percentage of unemployment

$\%$

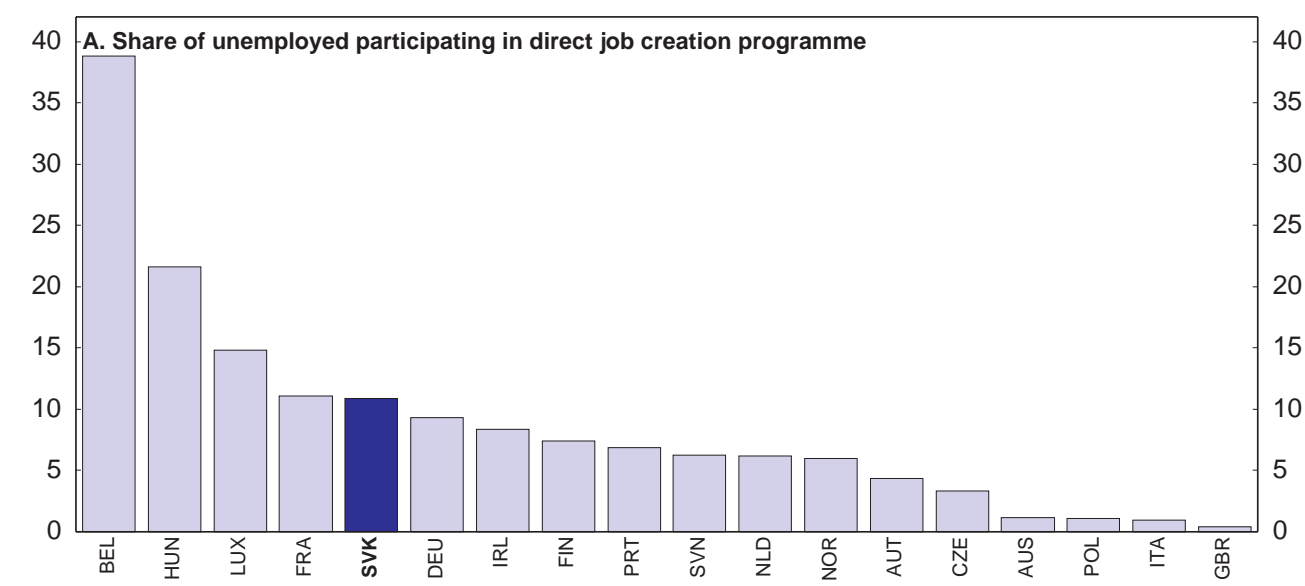

$\%$

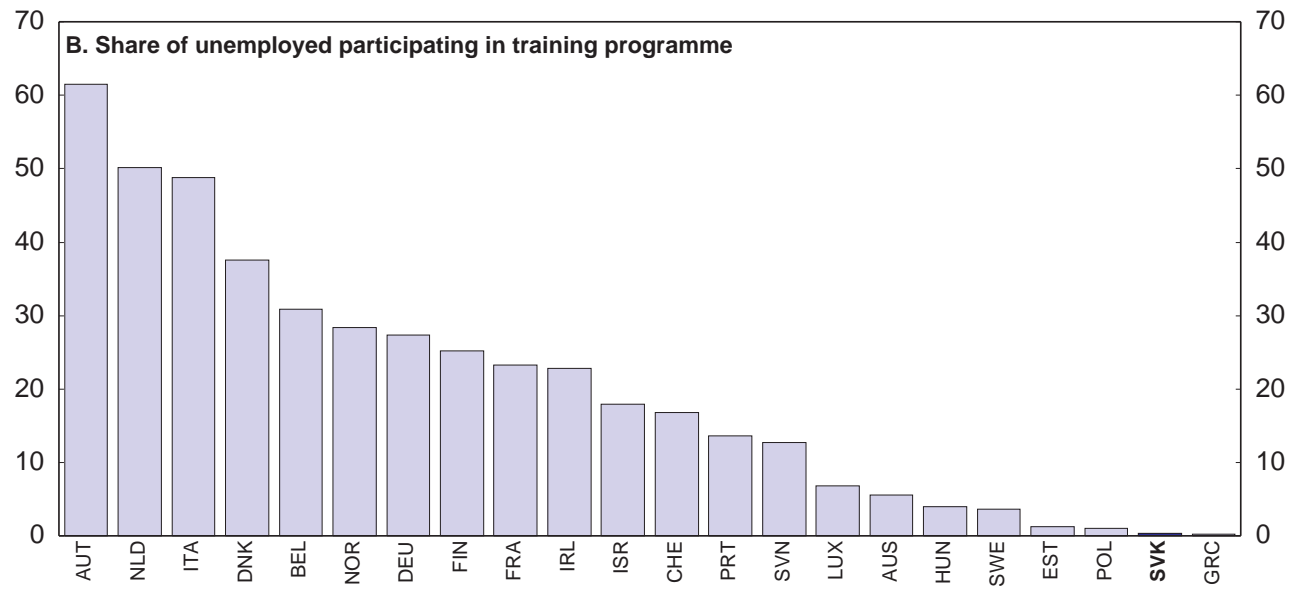

Source: OECD Economic Outlook database and OECD, Labour Market Programme database.

\section{Expanding employment incentives}

Employment incentives for employers - wage subsidies in particular - are found to foster employment but also to induce high deadweight losses when not targeted (Kluve, 2010; Martin and Grubb, 2001). For instance, evaluations of wage subsidies in Australia, Belgium, Ireland and the Netherlands have suggested combined dead-weight and substitution effects amounting to around $90 \%$, implying that for every 100 jobs subsidised by these schemes only ten were net gains in employment. Hiring subsidies are more effective when they compensate for shortfalls of individual productivity and encourage employers to supply jobs for the most disadvantaged jobseekers.

In Slovakia, labour taxation is relatively high for low-paid jobs: the tax wedge for a single person earning $67 \%$ of the average wage is 4 percentage points higher than the OECD average. This limits the employment chance of low-productivity workers, who make up the largest share in the unemployment pool. Measures aiming at subsidising firms for employing disadvantaged jobseekers - the Allowance to support employment of a disadvantaged jobseeker and the Allowance for induction of a disadvantaged jobseeker - have been implemented but have not been extensively used. Only around 700 jobs were created under these measures in 2011. The reasons behind this low pick-up should be assessed and the 
measure should be amended based on this analysis. It is planned that EUR 50 million (EU funds) will be allocated to support employment. Wage subsidies should be extended as planned but should also be tightly targeted to long-term jobseekers with low productivity. Placement of long term unemployed into firms could be also directly promoted, for instance by reducing hiring costs (PES staff select and train disadvantaged job seekers for the firm). Such initiatives proved to be effective in the past (e.g. US Steel in Kosice implemented a programme for Roma employment in cooperation with local authorities).

Employment incentives also include the "Graduate Practice" a measure targeted at youth employment. This programme offers to every youth unemployed for at least 3 months irrespective of its qualification level or work experience a three to six months internship to acquire and improve professional skills and practical experience (maximum 20 hours per week). It is financed by an allowance paid by the labour office at the minimum subsistence level (EUR 195 per month since July 2012). According to available evidence, around $42 \%$ of participants found a job after the programme in 2011. However, Harvan (2010) points to a low net positive effect of the measure on the employability of participants: participation in this programme increase the chance of getting into employment on average by 3 percentage points. This may be due to the fact that firms select candidates they may have hired even in absence of programme (World Bank, 2012a). The impact of the measure on the level of qualifications and on the quality of jobs participants get after the programme is unknown. The programme does not require firms provide formal training and this may limit the positive effect of the measure on the employability of participants. As recommended in OECD (2007a), the programme should offer certified qualifications.

\section{Putting more emphasis on training measures}

According to available evidence, well-designed training programmes contribute to reducing unemployment. Studies on aggregate data show that spending on training is associated with better labour market outcomes (e.g. Boone and van Ours, 2004). Bassanini and Duval (2006) find that increasing ALMP spending on training programmes per unemployed as a percentage of GDP per capita by 4 percentage points would reduce unemployment by at least 0.2 percentage points in the average OECD country. By broadening the availability of skills on the labour market, training could help to address labour shortages and to reduce skill mismatch. Also, by improving the adaptability of workers and avoiding the erosion of their competences, training may reduce the risk of future unemployment spells and open new job opportunities to the job seekers. Finally, these programmes help to maintain job seekers in contact with the labour market and may reduce drops-out from the labour force.

Training accounted for only $2 \%$ of total spending on ALMP in Slovakia in 2010, reaching $0.01 \%$ of GDP, among the lowest amounts in the OECD. Spending on training declined to a level close to zero in 2011 and the participation rate had been divided by four between 2004 and 2010 (Figure 7, lower panel). The low level of spending on training has three main causes.

- First, not enough stable funds are available for labour offices to finance training measures. As mentioned above, funds are allocated in priority to mandatory programmes (programmes that must be systematically provided to jobseekers according to law) and training is optional. The under-funding of ALMP, partly due to the low absorption of EU funds, requires financing mandatory programmes with funds initially allocated to training.

- Second, the provision of training programmes is undermined by burdensome procurement rules and the low administrative capacities of PES. Thus, training should be supported by simplifying public procurement procedures and training PES staff in procurement law. The relaxation of procurement rules should be accompanied by the introduction of outcome-oriented funding. For instance, the certification of acquired competences should be required or employment outcomes 
monitored. This would encourage suppliers to improve the quality of training and facilitate the recognition of the qualification acquired during the training on the labour market.

- $\quad$ Third, programmes are designed at the central level and do not appropriately reflect specific local needs. Also, the delay in delivery contributes to the mismatch between supply and demand of training. The determination of programmes should be decentralized and a sufficiently large range of programmes should be made available to adapt to individual needs (from basic life-skills to specialized competences) and encourage the participation of long-term job seekers to such activation programmes.

Among training programmes, job-search courses (CV writing, preparing for a job interview, building a network) are found to be quite effective even in the short run (OECD, 2007c). In Finland, job-search assistance courses increased employment probabilities by 4 percentage points on average, with relatively greater impact for individuals who have less education (Duell et al., 2009). In Austria, a job-search training programme was estimated to reduce the remaining duration of the unemployment spell by about one third (Grubb et al., 2009). Thus, job-search training programmes should be provided in particular to those unemployed without any experience of job search (e.g. school leavers). By contrast, the positive impact of some training programmes on employment, including on-the-job training programmes, only materialises after some time (Card et al., 2009). Such programmes may not be efficient for reducing unemployment in the short run. Also, given the relatively high cost of training, the effectiveness of the programmes should be carefully assessed before being provided.

The impact of training programmes on labour market outcomes depends significantly on their design (Martin and Grubb, 2001). Some best practices could be drawn from international experience:

- Training should be well targeted and the programmes should also be tailored at the specific needs of targeted groups (Meager, 2009). In Slovakia, training is mainly provided to unemployed who have found a job but need a training to be hired. Van Ours (2000) points out that the positive effect of training measures on the job finding rate of participants may be due to this selection bias. Disadvantaged jobseekers are under-represented in the training programmes. $39 \%$ of the participants were low skilled ( $v s$. $60 \%$ overall), 30\% were long term unemployed ( $v s .60 \%$ overall) and $12 \%$ were young (vs. $21 \%$ overall).

- Programmes should include a significant on-the-job component (Martin and Grubb, 2001). International experience also suggests that training is more effective when addressing the needs of local employers (Duell et al., 2009). A close link between the PES, local companies is advisable to monitor closely the required skill development. In Austria "placement foundations" were set up to identify skill shortages at the regional level and provide adequate training to the unemployed. These foundations involve a close cooperation and networking between PES and employers and training providers (Duell et al., 2009). For youth, good practice is also to combine training with an experience of second-chance education, which provides a mix of adult mentoring, work experience and remedial education (OECD, 2010a).

- Training should provide participants with qualification standards, which could be easily recognized by the employers and prove achieved skills and qualifications (Poppe et al., 2003). In Germany, some training programmes (the specific professional skills and technique training programme) including workplace experience and the certification of acquired competences has been found to improve the employment rate by about ten percentage points a year after the beginning of the programme (Meager, 2009). 


\section{Box 1. Recommendations for improving active labour market policies}

Make activation policies more widely available for those in need

- $\quad$ Encourage job search activities and participation in Active Labour Market Policy (ALMP) by all benefit recipients with some ability to work by making their registration in placement services and participation in activation measures mandatory.

- Increase spending on those ALMPs whose effectiveness has been demonstrated. Implement the planned data collection and systematic evaluations of ALMP. Consider testing new programmes with pilot projects before implementing at the national level.

- $\quad$ Target ALMP towards those who are more in need and make programmes more client-oriented. Identify the pockets of underperformance and analyse the labour market outcomes of at-risk groups. Set specific performance targets regarding disadvantaged groups at the local level.

Strengthen the Public Employment Service

- Allocate more resources to placement services in Public Employment Service (PES). Develop accountability of local labour offices for instance by increasing the role of performance in contract renewals and staff remuneration.

- $\quad$ Reorganize the PES by creating one-stop shops. Strengthen the registration of vacancies and increase resources allocated to collect information on labour market developments. Establish an effective online collection of job offers.

Improve the effectiveness of activation programmes

- Develop employment incentives targeted towards long-term job seekers with low-productivity. Foster the placement of long term unemployed into firms, for instance by reducing firms' hiring costs.

- Propose job creation programmes only when no other options are available. Exclude early school leavers from these programmes and complement them with other activation measures improving employability.

- $\quad$ Support training by simplifying public procurement procedures and providing adequate training to PES staff. Introduce strong incentives for training providers to offer high quality and job-oriented training, for instance by establishing outcome-oriented funding and requiring the certification of acquired competences. Provide a sufficiently large range of programmes adapted to individual needs. Provide short training on job search at an early stage, in particular to youth unemployed.

- $\quad$ Strengthen eligibility criteria and the monitoring of start-up incentives.

\section{Investing efficiently in education}

\section{Educational outcomes are below OECD averages}

The performance of the education system is significantly below the OECD average both in terms of education level and education quality. The education level is low, with around $24 \%$ of those aged 25-34 with a tertiary education level degree (37\% on average in the OECD). At the same time, educational attainment is rising strongly with around $50 \%$ of young graduating from tertiary education in 2010 (Figure 8, lower panel). Regarding the quality of education, despite some improvement since 2006, indicators point to low performance. While the aggregate PISA score has improved since 2006, it is still below OECD average (488vs. 497 points). The impact of socioeconomic background on students' results in PISA is close to the OECD average (Figure 8, upper panel). However, for some groups, inequalities on the access and the quality of education are substantial. Educational outcomes of the Roma minority are particularly poor: more than $70 \%$ of the Roma population have a less than upper secondary education and Roma do not attain tertiary education (Table 3). Geographical inequalities are also high. On average PISA 
scores are around $10 \%$ lower for students attending schools located in a village compared to students attending schools located in a city, the fourth highest negative gap in the OECD (OECD, 2011a).

Figure 8. Educational level, average Pisa score and impact of the socio-economic background

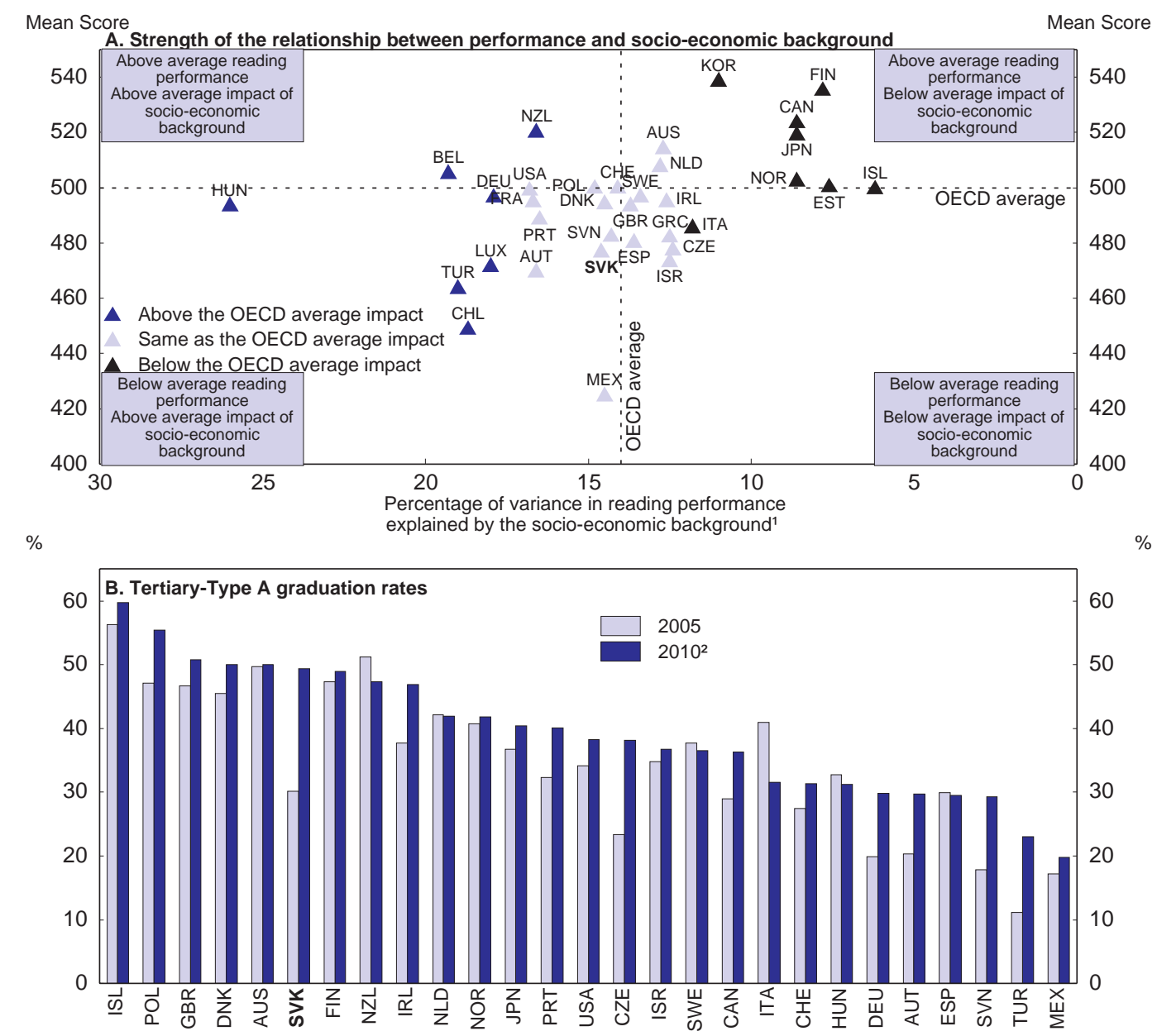

1. PISA index of economic, social and cultural status ( $r$-squared $x 100$ ).

2. 2009 for Australia and Canada.

Source: OECD (2011), Education at a Glance, Chart A5.2 and OECD (2012), Education at a Glance, Table A3.2.

Table 3 Educational attainment of the Roma population

\begin{tabular}{lrrrr}
\hline & \multicolumn{2}{c}{ Men } & \multicolumn{2}{c}{ Women } \\
\hline & Roma & Total population & Roma & Total population \\
\hline Basic education & 5 & 0 & 7 & 0 \\
Lower secondary education & 63 & 4 & 70 & 7 \\
Upper secondary & 32 & 74 & 24 & 71 \\
Tertiary education & 0 & 22 & 0 & 22 \\
\hline
\end{tabular}

Source: World Bank (2012b)

\section{Improving educational outcomes would be highly beneficial}

Increasing the education level of the Slovak population is likely to increase productivity and the employability of the working age population. Public and private returns on education are relatively large by OECD standards, especially in the form of finding a job (Šiškovič, 2011). They increase significantly 
with the level of qualification, reflecting the higher level of remuneration and tax associated with higher educational attainment (OECD, 2011a). The present net value of education is particularly high, public and private internal rate of returns of education being 2 to 22 percentage points above the OECD averages (Šiškovič, 2011).

Improving educational outcomes would also have a significant positive impact on economic growth. An additional year of schooling may increase growth in real GDP per capita by $10 \%$ (Bouis et al., 2011; Bils and Klenow, 2000; Psacharopoulos and Patrinos, 2004). An OECD study shows that improvements in the education quality can have a very large impact on future economic growth $(\mathrm{OECD}, 2010 \mathrm{c})$. Increasing average PISA scores to OECD highs (Finland) of all labour force participants would increase GDP growth by $0.9 \%$ in Slovakia. Reducing educational inequalities may also contribute to boosting labour productivity and utilisation (Causa and Johansson, 2009). Education is one of the main determining factors of economic and social outcomes thus raising educational outcomes of individuals with disadvantaged socioeconomic background would allow them to fully realize their potential (OECD, 2010d). Finally, increasing the level of education tends to increase public sector efficiency (Afonso et al., 2006) which is helpful in times of fiscal consolidation (OECD, 2012c).

While Slovakia implemented a large number of measures aiming at improving educational outcomes, most of the issues identified in past Surveys remain (chapter 3 of OECD, 2007b). The benefits of the reforms may take time to materialize. Nevertheless, additional effort needs to be made to ensure that education services are provided in the necessary quantity and quality. This includes reforming the allocation of funds in the education system by more directly taking into account performance and efficiency elements, increasing resources allocated to teaching activities, in particular for disadvantaged pupils, adapting vocational education to labour market requirements and developing the pre-conditions for lifelong learning. Some savings could be achieved by adopting best practices but they may not be sufficient or fast enough to finance the measures mentioned above. Thus, the education budget should at least be sheltered from budget cuts and consideration should be given to allocating additional funds to education.

\section{Public spending on education is low}

Despite increases over the past decade, spending on education is low by international comparison both in relation to GDP and as a share of total public spending. Between 2000 and 2008, expenditure per primary, secondary and post-secondary non-tertiary student increased by more than $40 \%$. However, in 2009, annual spending per student was only half the OECD average and Slovakia was the country which spent least on education in the OECD (Figure 9). Studies do not find a close relationship between the level of spending and the quality of education (OECD, 2012b). This suggests that increasing spending on education alone will not be sufficient to improve educational outcomes, but must be accompanied by structural reforms of the education system. 
Figure 9. Spending on education and Pisa score

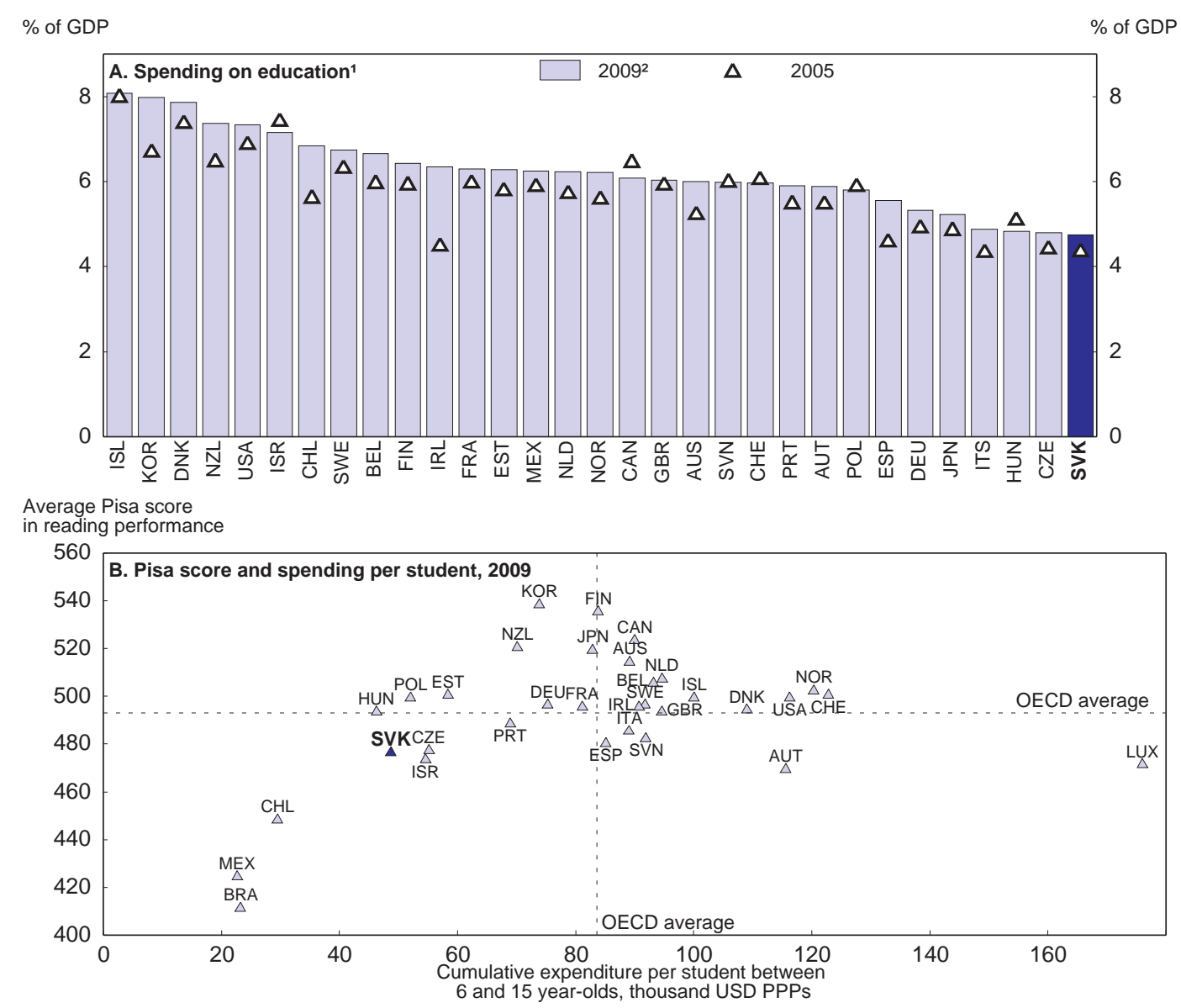

1. Public expenditure only for Hungary; for Switzerland, in tertiary education only; and for Norway, in primary, secondary and postsecondary non-tertiary education only.

2. 2008 for Canada and 2010 for Chile.

Source: OECD (2012), Education at a Glance, Table B2.1 and B1.3b; and PISA 2009 database.

\section{Achieving efficiency gains in the primary and secondary education systems}

The primary and secondary education systems are quite efficient by international comparison with relatively high PISA scores for a low level of spending (Sutherland et al., 2007, Grigoli, 2012). As a result, few gains can be made from moving to best practices, and the room from increasing educational outcomes without increasing resources is limited. At the same time, studies show that efficiency gains are possible (Mandl et al., 2008) and given the consolidation needs, every opportunity for efficiency gains should be seized.

Well designed institutional and policy settings of primary and secondary education can result in higher public sector efficiency (Joumard et al., 2003). Three main characteristics of public institutions are identified as having an impact on efficiency: the capacity to allocate available resources efficiently; the efficiency of budget management once priorities are set; and the efficiency of services provision (Gonand et al., 2007). According to available indicators, the funding system of primary and secondary education could be improved in Slovakia, while the institutions dealing with the budget management and the provision of educational services at the local level are well-designed and should thus be cost-efficient. 


\section{Reforming the funding system}

The allocation of funds in the education system could be improved as it is not sufficiently oriented towards quality improvement. The responsibilities for budgetary allocation are not fully decentralized. The funding of schools is mainly determined by the number of pupils and the amount of funds allocated per pupils does not depend on outcome-related criteria. Schools funders have some room to distribute funds to address specific needs. A share of funds can be redistributed among schools at the local level $(10 \%$ of the wage costs and $20 \%$ of the non wages costs). Also, some additional funds could be allocated on demand of the school funder (pupil transportation costs, teaching assistants, exceptional achievements of pupils, emergency situation) but there are limited.

The funding formula encourages the separation of pupils according to their educational achievement. Premiums are allocated to eight-year grammar schools (schools for the best pupils selected at age 10) which receive around $12 \%$ funding premium. Additional funds are also provided for children with special needs but they are not sufficient to encourage the integration of these pupils in standard classes or schools (Friedman and Suru, 2009). As a result, the funding system encourages the creation of special schools either for the best pupils or for those with difficulties. This is inefficient as regrouping pupils according to educational outcomes may have no impact on overall educational outcomes and by contrast tends to increase the influence of socio-economic background on learning outcomes (OECD, 2010d). The funding of basic schools and eight-year grammar schools will be harmonized by removing premiums to eight-year grammar schools in 2013. This is a first step in the right direction. One step further would be to delay the age at which first selection into education tracks is made as recommended in the 2007 Survey (OECD, 2007b). Also, incentives to integrate pupils with special needs in standard classes should be strengthened.

\section{Revising the network of primary and secondary schools}

The network of primary and secondary schools could also be revised. Demographic change has lead to a decline in the number of pupils since 1990. However, the number of schools did not follow and the number of students per school decreased by one third between 1989 and 2011 . The class size and the number of students per teacher also declined and the class size is now below the OECD average (by around 3 students per class, Figure 10). Some economies of scale could be reaped by reducing the number of classes and schools (OECD, 2011a). When possible, schools should be encouraged to merge as this will contribute to reducing sunk costs and to improving efficiency: small schools tend to be less efficient than larger schools (Sutherland et al., 2007). Yet, the current funding formula discourages economies of scale. Additional funds are allocated to small schools, with the premium decreasing with the number of pupils. Replacing the premiums to small schools by grants not linked to the size of the schools would foster the merger of schools. The impact of the merger of schools on local development should be taken into account and the in-charge authorities should ensure the costs of the restructuring of the school network do not exceed the benefits. Increasing the size of classes would also free resources for more effective measures without damaging education quality: empirical studies indicated that the size of classes has no impact on educational outcomes (OECD, 2012b). To do so, the upper limit on size of classes fixed by law should be increased. 
Figure 10. Average class size and student-teacher ratio in primary and secondary education
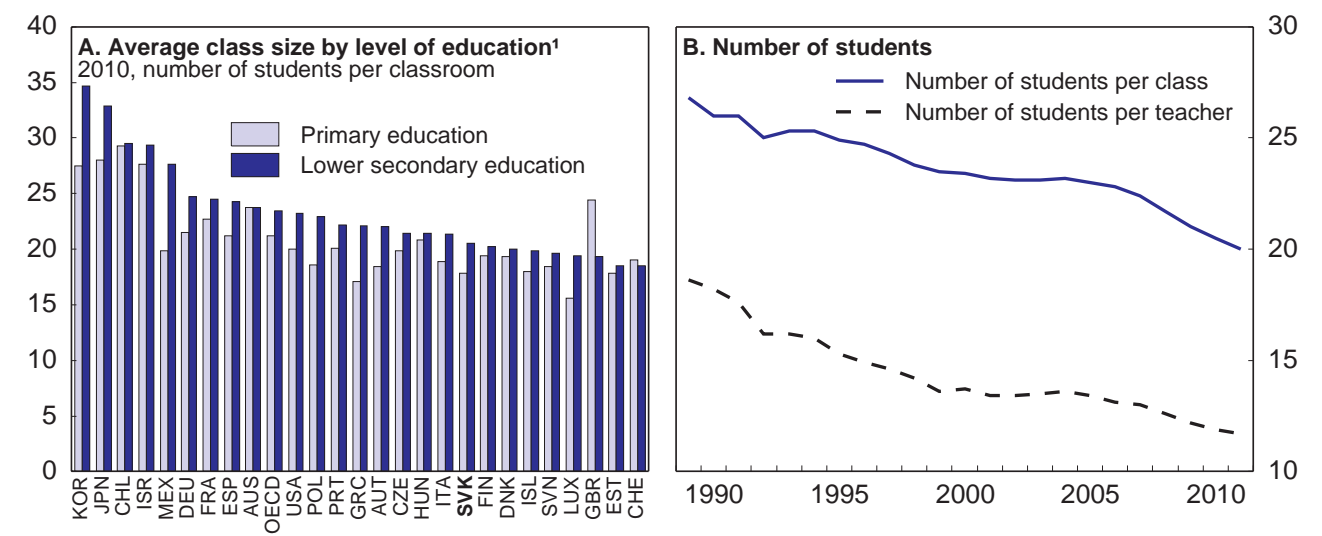

1. Public institutions only for Switzerland.

Source: OECD (2012), Education at a Glance, Chart D2.2. OECD calculations based on data from the Institute of Information and Prognoses of Education.

The structure of the secondary education network should adapt to the increase in tertiary education attainment. The government is planning to strengthen the selection of pupils entering grammar schools to avoid a "dumbing down" of general education. The government should make sure that the reforms envisaged do not undermine tertiary education attainment and that vocational schools are adequately preparing pupils to succeed in tertiary education (by providing sufficient general education). An option would be to integrate vocational secondary schools and grammar schools, with the general education courses common to both tracks being offered jointly, as recommended in OECD (2007b).

\section{Improving the evaluation of schools}

Recent reforms providing more autonomy to schools should improve the efficiency of budget management at the local level. Schools have total autonomy in spending their budget, hiring collaborators and defining the learning methods and the education programmes. ${ }^{4}$ Measures should be implemented to ensure that the high level of autonomy generates high quality outcomes and to monitor its impact on equity across schools. The accountability of the educational staff should be developed and incentives for improvement should be introduced (Gonand et al., 2007). Internal and external evaluations have been developed recently and are partly used to encourage performance. First, national examinations were established at the lower and upper secondary level. The government also envisages implementing evaluation of pupils at the primary level, allowing to assess the "value added" of schools. Second, the Ministry of Education is working on new rules for self-assessment of schools to increase accountability of the education system. Third, many output and outcome indicators about primary and secondary schools were published to increase public awareness about schools results, thus encouraging high performance.

The developments of assessment tools, targeted funding with allocation of resources to the areas with the highest needs, and an increased accountability of principals for the educational outcomes have a positive impact on educational outcomes (Mc Kinsey, 2010). Available evaluations should be used to identify dysfunctions and best practices, adapt and better target education policies. However, the Inspectorate only checks the compliance of education programmes with regulation, and information from internal assessment - often considered as an administrative burden - is not used to improve the quality of teaching. Also, published outcomes of schools are not relevant to assess the quality of teaching as they do not take into account the context of each school. Thus publishing these evaluations only generates superficial competition between schools and may finally lead to misinterpretation and cream skimming.

4. Compulsory knowledge is defined at the central level and should be included in education programmes. 
More accurate information about the quality of schools could improve parents or/and students decisions about school selection, especially where funding follows students (OECD, 2011a). Also, it would help to target schools with difficulties and encourage the diffusion of best practices.

\section{Increasing resources allocated to teaching activities}

The share of funding allocated to teaching activities and to the remuneration of teachers is low by international comparison. Relative wages of teachers are the lowest among OECD countries (Figure 11). Teachers' wages were only $44 \%$ of the average earnings of tertiary education graduates in Slovakia, while in the OECD average they varied from $77 \%$ and $89 \%$ depending on the education level in 2009 (OECD, 2011a). ${ }^{5}$ This is unfortunate as PISA results show that the best performing countries tend to invest more in teachers offering them higher salaries and greater professional status. By doing so, they tend to attract the best students into the teaching profession and then increase the quality of education (OECD, 2012b). In Slovakia, the low attractiveness of teaching positions causes difficulties in recruiting and retaining teachers with skills that are valued in the private sector, notably fluency in foreign languages (especially English). For example, 48\% of English lessons were taught incorrectly in the academic year 2010/11, and not all teachers were actually able to communicate in English (State School Inspection, 2011). Bringing up teacher remuneration to $75 \%$ of the average wage of a tertiary graduate would require a pay rise of around $50 \%$, costing around $0.5 \%$ of GDP. ${ }^{6}$

\section{Figure 11. Teachers' remuneration}

2010 or latest available year

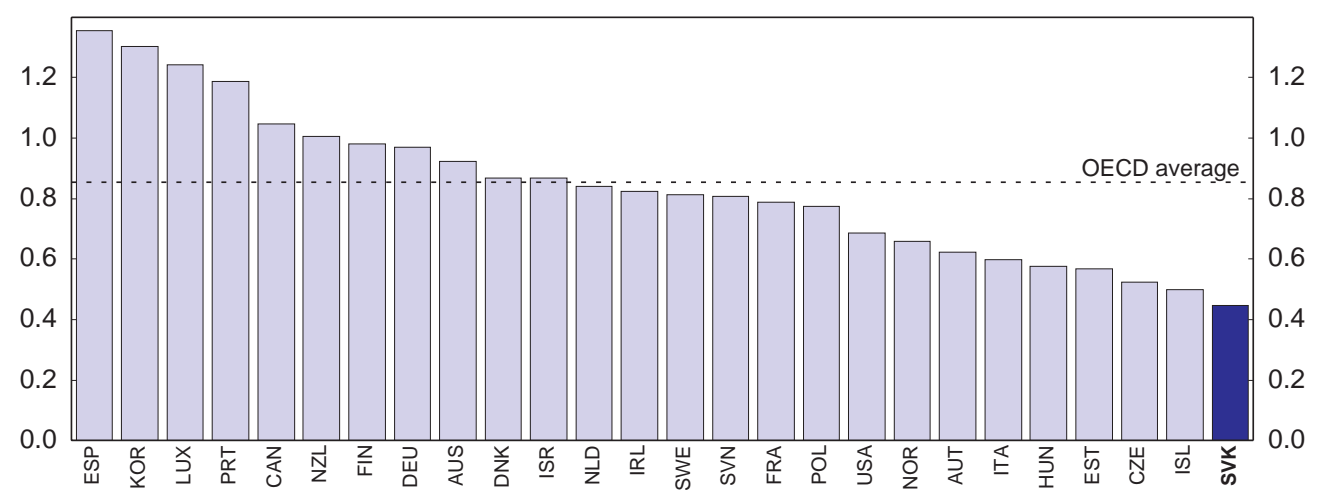

Note: Ratio of teachers' salary after 15 years of experience to earnings of full-time, full-year workers aged 25-64 with tertiary education.

Source: OECD (2012), Education at a Glance, Table D3.1.

The remuneration system of teachers is not creating incentives to improve educational outcomes as a very low share of teacher remuneration is outcome-based. School principals decide on the teacher remuneration for a small variable part (around 11\% of the wage bill in 2011) and the wage is mainly determined by the seniority of the teacher (for the same education level) and not by performance. By reviewing the successful experience in improving educational outcomes across the world, a Mc Kinsey

5. Also spending on ancillary services is higher than other OECD countries as a share of total expenditures on education. At least $10 \%$ of total expenditure by educational institutions is allocated to these services (transports, meals, housing etc.) in primary and secondary and post-secondary non-tertiary institutions.

6. $0.5 \%$ of GDP corresponds to an increase of the average wage of teachers of $50 \%$ multiplied by the total number of teachers in primary and secondary education (including social security contributions). The sources used are the UOE database for the number of teachers and OECD Education at a Glance 2012 for the average wage. 
study identifies best practices regarding management of educational staff. It shows that, for schools with low performance in PISA, teacher accountability should be improved (Mc Kinsey, 2010). To increase performance, teacher and school leadership professions should be made more attractive and collaborative practices between teachers and between schools should be valued to encourage sharing of best practices. The wages of teachers should be increased while at the same time creating incentives for quality improvement. This should be accompanied by a widening of performance monitoring and pay. Also, new career path for teachers should be created to improve the attractiveness of teaching positions. Senior teachers should be given the opportunity to have new responsibilities, such as supervising less experienced teachers.

Teachers have the opportunity to participate in some training during their career (including free training) and to receive premiums when they acquire new competences. However, Slovakia has the second lowest participation rate of teachers in professional development (after Turkey) among countries participating in the OECD Teaching and Learning International Survey (TALIS). Around 25\% of teachers did not participate in professional development in the previous 18 months in 2007-08, 14 percentage points more than the panel average $(\mathrm{OECD}, 2009 \mathrm{c})$. The low participation is due to the low availability of adequate training: $60 \%$ of non-participants state that they did not participate because of a lack of suitable training ( $v s .40 \%$ on average) while only a minority mentioned the cost of training and conflicts with work schedule as the main hurdles to participation. This suggests that training of teachers could be improved by providing adequate lifelong learning opportunities.

International experience indicates that apprenticeships and mentorship of educational staff has a positive impact on the quality of teaching (Mc Kinsey, 2010). In Slovakia, cooperation between the school leader and teachers is well developed at the school level and teachers have to complete a year-long adaptive educational programme with experienced colleagues before starting to work. However, cooperation between schools is weak, hampering the diffusion of best practices. Some practices such as having superintendents discussing regularly with principals and teachers on school achievement, suggesting solutions and getting feedbacks could help in this respect. Appointing specialized and experienced teachers to work in different schools and providing recommendations to teachers during a few weeks would also contribute to increasing the quality of teaching.

\section{Concentrating efforts on disadvantaged pupils}

Providing a minimum education level to every citizen is crucial to avoid social exclusion and improve labour market outcomes. Individuals with a low performance in basic skills (literacy, numeracy and problem solving) are more likely to be unemployed, permanently detached from the labour market, and not to train during their adult lives (OECD, 2011b). In Slovakia, $85 \%$ of the population are graduated from upper secondary education. However, the share of youth who do not have a minimum reading proficiency is large by OECD standards: $22 \%$ of pupils achieved only a low level of reading proficiency in PISA, 3.5 percentage points more than in the average OECD country. Literacy skills of Roma are particularly poor, contributing to their detachment from the labour market (World Bank, 2012b). According to PISA scores, best performing school systems are those which commit themselves to ensuring that all students succeed (OECD, 2012b). This suggests that more resources should be provided to ensure a minimum education level for all and should be concentrated on pupils with difficulties, the Roma in particular.

Good-quality early childhood education has a positive impact on future educational outcomes, in particular for children from socio-economically disadvantaged backgrounds (OECD, 2010d). Roma children attending pre-school are less likely to enrol in special school and to be on the social assistance in the future (World Bank, 2012b). Even though several measures were implemented to encourage participation in pre-primary education of children from low socio-economic background, participation of Roma children remains low (Šiškovič, 2012). For example, pre-primary education is free of charge one 
year before compulsory education starts and for children who come from families that receive material need benefits. However, only $20 \%$ of Roma children aged 3-6 years attended kindergarten (vs. 55\% for children from same area, UNDP, 2012). The pre-school enrolment rate of Roma in Slovakia is low compared to neighbouring countries. In Hungary $76 \%$ of Roma children attend pre-school and the gap in secondary school completion rates among Roma and non-Roma neighbours is two-third lower than in Slovakia (World Bank, 2012b). The participation of low income families and Roma in pre-primary education should be further encouraged by making pre-primary education mandatory, as in Hungary.

While it is prohibited by law, segregation of Roma children at primary and secondary school remains prevalent (Amnesty International, 2010; FRA and UNDP, 2012). Roma children are disproportionally placed in special schools or in special classes after being diagnosed as mentally disabled. Despite policy actions preventing unjustified placement of Roma children in special schools, the attendance rate of Roma in special schools has almost doubled in one generation (World Bank, 2012b). This is unfortunate not least because regrouping pupils with special needs undermines their chances to succeed in higher level of the education system. Indeed, educational achievements significantly depend on peer group effects (Sutherland et al., 2007). Roma are particularly disadvantaged due to their low socio-economic background and the lack of language proficiency. Being grouped into special schools or classes, the children have more difficulties in learning the Slovak language in particular. Also, according to PISA scores, best performing school systems do not separate out poor performers or students with behavioural problems or special needs (OECD, 2012b).

Overall, policy initiatives to improve Roma integration in the education system have been largely unsuccessful (Vagac, 2010). However, some measures, following international best practices, are going in the right direction. Schools with more than 100 pupils from low socio-economic background have to use at least $50 \%$ of additional funds to remunerate teaching assistants. The appointment of assistants speaking Romani is also very welcome. A new Roma Integration Strategy has been recently defined in collaboration with the EU Commission (European Framework for National Roma Integration Strategies) with promising action programs (Box 2). Policy measures defined in this Strategy should be quickly implemented, results should be monitored and programmes should be adjusted accordingly. In particular, plans to reform the tracking system of children into special schools and to increase the number of teaching assistants are very welcome.

\section{Box 2. Policy initiatives to raise educational outcomes of the Roma population}

The main goal of the Strategy of the Slovak Republic for the integration of Roma up to 2020 (January 2012) in the area of education is to improve access of Roma to quality education from the early childhood to university with special emphasis on removing possible segregation at schools, prevent premature termination of school attendance and ensure a smooth transition from school to work. The main policy objectives are notably:

- Increase the participation of children from socially disadvantaged environment in pre-primary education to $50 \%$ by 2020 .

- Improve motivation, school results and attendance of Roma children in elementary schools and ensure that the below secondary education level is reached by $100 \%$ of all pupils.

- Increase the proportion of Roma students who reach upper secondary education level to the level of general population of the Slovak Republic.

- Increase the proportion of teachers and specialists fluent in Romani.

- Exercising the right to education in a Romani language, providing education for teachers of Romani language and preventing all forms of discrimination.

- Improve the process of diagnostics and placement of children into the system of special education and remove sources for unjust placement.

Policies measures are defined in the revised National Action Plan of the Slovak Republic regarding the 
Decade of Roma inclusion 2005-2015 for years 2011-2015 and include notably:

- Develop incentives to participation in pre-primary education by providing free of charge pre-primary education from age 3. Increase pre-primary education capacities in municipalities with high numbers of pupils from socially disadvantaged environment.

- Increase the funding premium for pupils from socially disadvantaged environment by $100 \%$. Increase number of school special educators, school psychologists and teaching assistants.

- Improve the process of diagnostics and placement of children into the system of special education by elaborating socially and culturally relevant tests of schooling competency, during the testing using the child's mother tongue, and if necessary, ensuring the presence of teacher assistant for pupils from socially disadvantaged environment.

\section{Improving the transition from school to work}

Transition from school to work is difficult, in particular for youth with basic or below upper secondary education. Graduates from upper secondary schools have also more difficulties in finding a job compared to tertiary graduates. The unemployment rate of 25 to 29 olds not in education or in training was more than seven percentage points higher for those having an upper secondary education level than for those with a tertiary education level in $2010(13 \% v s .6 \%)$. The gap is significantly lower in the average OECD country (two percentage points).

A large share of the youth population is graduated from vocational schools. In $2009,72 \%$ of upper secondary students were enrolled in pre-vocational or vocational programmes and $64 \%$ of the population has graduated from vocational or pre-vocational programmes, 20 percentage points more than the OECD average. The unemployment rate for graduates from vocational schools is close to the unemployment rate of graduates from general education on average (Table 4). ${ }^{7}$ However, graduates from vocational schools not preparing to enter the university (not preparing the maturita), with more vocationally-oriented curricula, face higher risks of being unemployed. Also, the unemployment rate of 24-35 olds graduated from vocational schools is four percentage points higher than for those graduated from general education, suggesting that graduates from vocational schools have more difficulties in finding a first job. This is worrisome as graduates from vocational schools are supposed to enter the labour market directly after graduation.

Table 4. Unemployment rate by educational attainment level

\begin{tabular}{lcc}
\hline & $\mathbf{2 0 0 6}$ & $\mathbf{2 0 1 1}$ \\
\hline Total & $\mathbf{1 3 . 3}$ & $\mathbf{1 3 . 5}$ \\
\hline Basic education & 48.0 & 42.1 \\
Vocational upper secondary education & & \\
$\quad$ Vocational without maturita & 15.4 & 16.8 \\
$\quad$ Vocational with maturita & 12.7 & 12.2 \\
General upper secondary education & 9.5 & 14.6 \\
Tertiary & & \\
$\quad$ Bachelor degree & 4.7 & 7.8 \\
Master degree & 3.2 & 5.6 \\
\hline PhD. Degree & - & 4.2 \\
\hline
\end{tabular}

Source: National Statistical Office Note: LFS methodology

7. The integration of vocational schools graduates on the labour market depends on their specialization with unemployment rates varying between $7 \%$ in medical and pharmaceutical field and 34\% in agricultural and veterinary field in 2011 (Institute of Information and Prognoses of Education, 2011). 
The high unemployment rate of graduates from vocational schools is likely to reflect a skill mismatch issue. The increasingly high level of youth unemployment does not coincide with a high school drop-out rate. Graduation rates have significantly improved over the past decade. Most of youth are qualified and graduated at the end of their studies. The enrolment rate at age 16 (the legal age to leave school) is slightly above the OECD average and the school drop-out rate is among the lowest in the OECD (Figure 12). According to recent indicators, the level of qualification of the Slovak population (with a high share of graduates from secondary education) fits well with the labour market requirements. The rate of overqualified or under-qualified is low by international standards (Quintini, 2011) meaning that workers have jobs that correspond to their education levels. However, competences acquired in vocational schools do not match labour market needs as the existing curricula do not sufficiently adapt to the changes in skill in demand and lead to out-dated qualifications (OECD, 2010a).

Figure 12. Early school leavers

Percentage of youth aged 20-24 not in education and without an upper secondary educational attainment, 2010

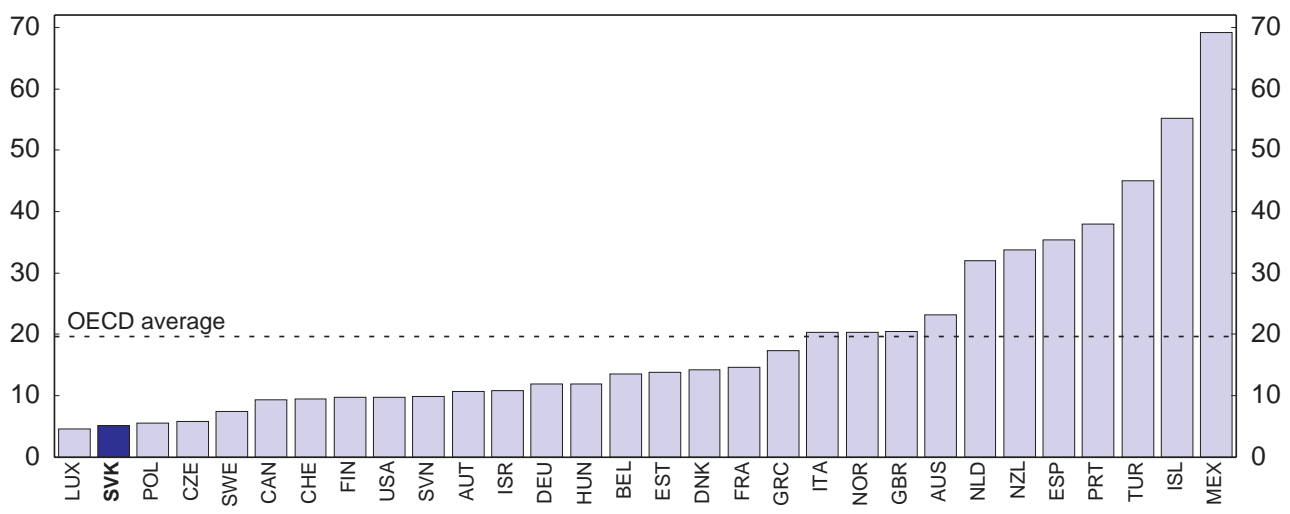

Source: OECD, Scoreboard for youth aged 15-24.

2006 PISA results show that business and industry had little influence on school curricula in Slovakia compared to countries with a strong vocational education and training (VET) system like Germany and Austria. To improve the matching between employers' requirement and vocational education mechanisms to regularly identify current and future labour market needs have been developed since then. VET councils at the national, sectoral and regional levels were established in 2009. These councils, involving employers represented by professional associations, are responsible for reviewing the curricula of VET schools and for defining a list of competences graduates must acquire. While it is too early to assess the effectiveness of these councils, they should be closely monitored and in-charge authorities should ensure a close cooperation between the different councils.

When defining educational programmes, a good balance needs to be found between providing narrow skills that increase the chances for immediate employability and general skills that develop adaptive capacities to structural shifts in the economy (OECD, 2007a). General knowledge should be part of the curricula as they are source of productivity growth and essential to innovation (Hoeckel, 2008). The system of competency-based curricula introduced in 2008 and including transferable knowledge should ensure this balance is found. Firms are increasingly demanding general knowledge, such as digital literacy, business skills and languages. This change in skills in demand towards more general knowledge reflects the upgrade in skills requirements (Handel, 2012). Demand for high skilled workers is likely to further increase in a catching up country like Slovakia. At the moment, tertiary education is characterized by long and academic programmes. Short (2-3 years) and vocationally-oriented tertiary programmes, which would better fit firms demand, are underdeveloped. The share of graduates from tertiary-B programmes among total tertiary graduates is among the lowest in the OECD (Figure 13). These programmes should be developed as they 
could bring tertiary education closer to the labour market needs. They would also reduce the length of studies, while being more accessible to VET graduates willing to pursue their studies.

\section{Figure 13. Vocational programmes in tertiary education}

Percentage share of tertiary type-B enrolled students in tertiary education, 2010

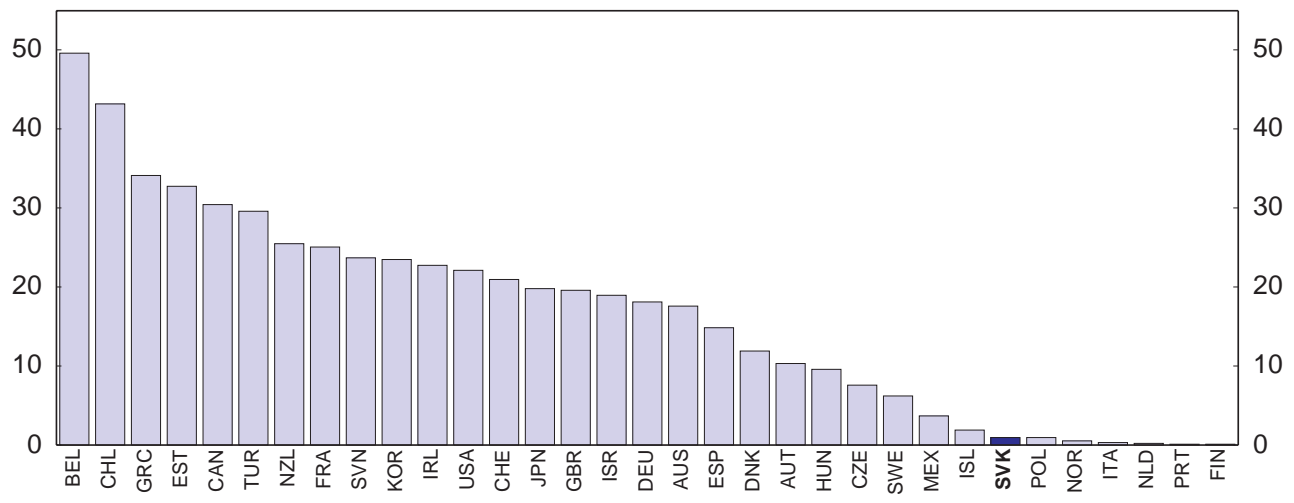

Source: OECD, Education database.

Studies show that in-work training improves school-to-work transition for VET graduates (Hoeckel, 2008; OECD, 2010e). The learning in the workplace offers several advantages: it allows trainees to develop 'hard' skills on modern equipment, and 'soft' skills, such as teamwork, communication and negotiation, through real-world experience. Workplace training also facilitates recruitment by allowing employers and potential employees to get to know each other, while trainees contribute to the output of the training firm. Workplace learning opportunities are also a direct expression of employer needs, as employers will be keen to offer opportunities in areas of skills shortage (OECD, 2010e). In Slovakia, only $30 \%$ of students in VET schools participated in some form of workplace training, suggesting that the current VET system is not attractive for firms. Recent reforms tend to encourage the involvement of firms in the VET system. The 2009 Act on VET introduced tax deductions for employers participating in training of VET pupils. Acquisition of professional experience during studies should be further fostered.

Dual apprenticeship systems deliver outcomes in terms of skill acquisition that appear to better equip workers to take advantage of changes in labour demand (OECD, 2012a). In this system, pupils alternate work and class and are directly employed by the firm, thus being fully integrated in the labour market while studying. However, conditions to set up an effective apprenticeship may be difficult to meet (Box 3). Thus, the authorities should support the development of apprenticeship, for instance in some sectors as pilot projects. At least, a legal framework for a dual apprenticeship system should be established and curricula with training standards should include more compulsory internships. These options are currently envisaged by the government and should be supported further.

\section{Box 3. Introducing an effective apprenticeship system}

All OECD member countries offering apprenticeship as a main route from school to jobs (Austria, Germany, Switzerland) have relatively low youth unemployment rates. While this success is well documented (OECD, 2010a), it is not completely clear why not all countries introduce or develop a dual vocational education system. This may be due to the fact that a gradual transition from a school-based to a work-based system is difficult and that some conditions need to be met to ensure the effective implementation of an apprenticeship system.

- $\quad$ Effective apprenticeships provide specialised vocational training to a large part of a cohort. It is not a minority programme for low achievers, but an attractive preparation for gaining a good job. Such programmes, where existing, are therefore an acceptable choice for parents and youth when making 


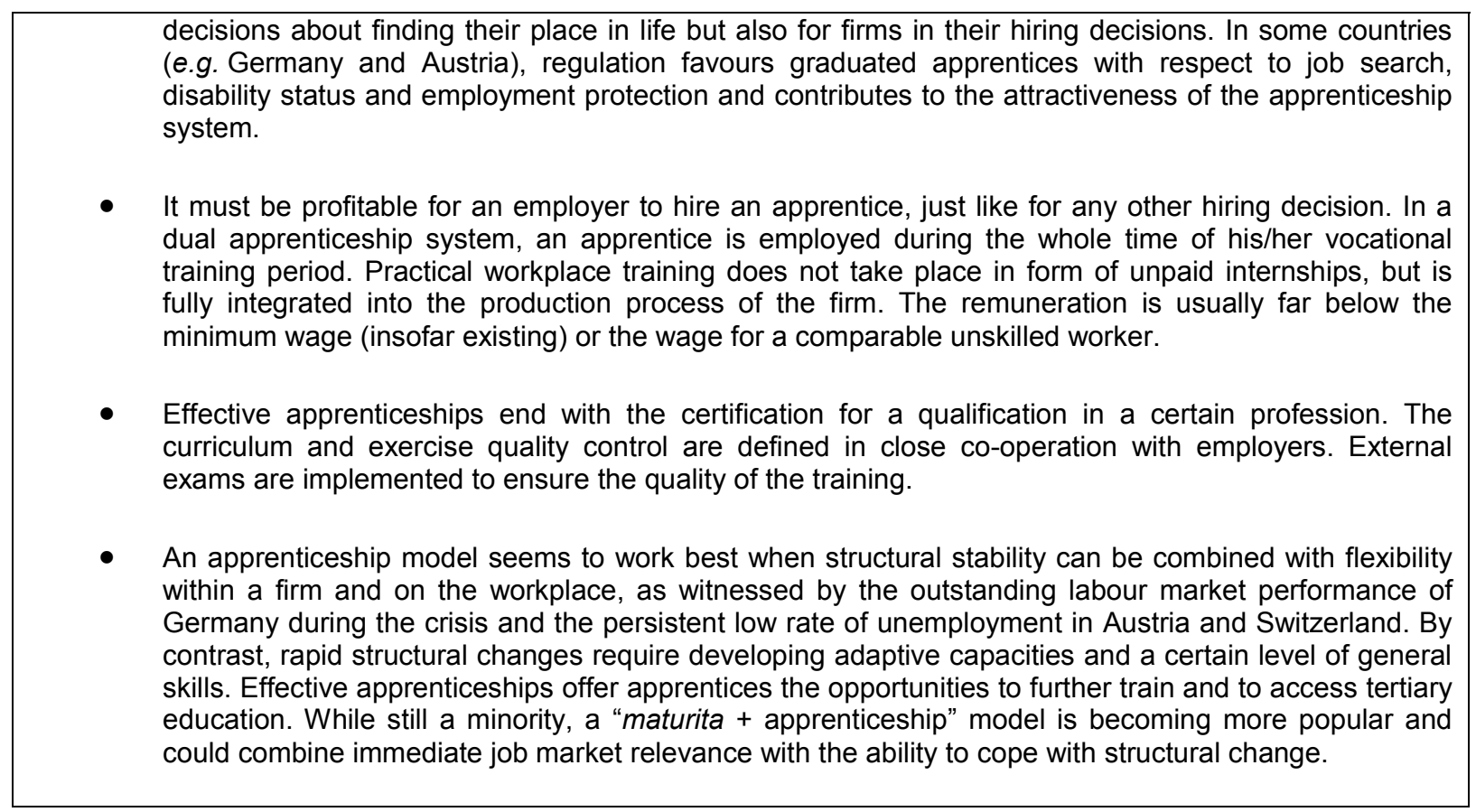

A system of certification of competences acquired in the VET system at the national level could facilitate matching on the labour market. Currently, the final assessment of competences is done at the school level. In the absence of national standards for assessment of competences, the tasks defined for the final exam by individual institutions may fit the facilities in schools, and the knowledge of local teachers, but not reflect wider requirements. Consequently, the certificate provides employers with limited information on the nature and level of graduate preparation hampering the recruitment of VET graduates (OECD, 2010e). By contrast, a certificate based on performance in a national assessment is a better predictor of productivity than a diploma obtained in a local assessment (Backes-Gellener and Veen, 2008). Since 2008, competency-based curricula have been established based on national standards and certificates delivered by VET schools include information on the competences acquired. It is also important to provide a consistent method to assess the learning outcomes of vocational programmes to ensure that all those with the same qualification have the same mix of competences, at a similar level.

\section{Developing lifelong learning}

Developing lifelong learning is essential to avoid skill mismatch due to structural changes in labour market needs. Lifelong learning is also a way to increase labour productivity by broadening the level of skills and to improve the employment prospects of early schools leavers and low skilled unemployed (OECD, 2011b). In 2007, the participation rate in non-formal education was relatively high in Slovakia by international comparison ( $41 \%$ vs. $34 \%$ in the OECD on average, OECD, $2011 \mathrm{a})$. However, the number of training hours per participant is relatively weak leading to a smaller number of expected hours in training during a working life ( 828 hours vs. 988 hours on average in the OECD). Strategies aiming at developing lifelong learning were established in 2007 and 2011 but only a few measures have been implemented since then (Box 4).

Providing information on the quality and returns of training and ensuring recognition of learning outcomes in the labour market and in the educational system is crucial for the good functioning of the training market. Individuals are more likely to invest in training if the competences they will gain with training could be identified and valued by the future employers. In 2009, a regulatory framework for the accreditation and the assessment of training programmes has been created. Some measures aiming at 
easing the recognition of competencies acquired trough non-formal education and at improving information on training programmes have been phased in. A National System of Occupations describing occupations and qualification they require is being established in co-operation with the private sector. A Further Training Information System is also created to improve access to information on training options. These initiatives might strengthen investment in training by reducing some informational failures and should be pursued further. At the same time, to avoid overlaps and duplications, they should be coordinated with other projects dealing with the identification of labour market requirements. In particular, the authorities in charge of establishing the National System of Occupations should coordinate with the abovementioned VET sector councils in charge of defining the educational programmes in VET schools.

\section{Box 4. National measures to develop lifelong learning}

The Slovak government approved the first Lifelong Learning and Lifelong Guidance Strategy in 2007. The Act on lifelong learning adopted in 2009 set a new regulatory framework for continuing education, for the accreditation and the assessment of training programmes as well as the basis for the recognition of non formal education. A new Strategy of Lifelong Learning approved by the government in 2011 defines new key priorities and some actions plans including:

- $\quad$ Creating a network of legitimate institutions for recognition of qualifications acquired during training;

- Establishing a system of communication between educational institutions and employers for common exchange of information on knowledge, skills and competences needed in the labour market;

- $\quad$ Creating an integrated information system devoted to career guidance providing information on training opportunities;

- $\quad$ Creating a network of career guidance centres enabling direct consultations with professional career advisors;

- Developing a funding tool to support lifelong learning.

No concrete measures have been implemented yet.

Private incentives for lifelong learning are weak (GHK and Research voor Beleid, 2011). Adult education is mainly financed with public funds, the private sector being marginally involved. ${ }^{8}$ The low share of co-financing suggests that lifelong learning policies are insufficiently oriented towards business needs.

- At the firm level, few incentives are provided to employers for training. To ensure employers get a return on their investment, payback clauses obliging employee to reimburse the training costs in case of voluntary quits have been introduced. Vouchers have also been proposed but were not used by firms. This is partly due to the design of the measure: around 30\% of the employers declare not using the voucher because of too burdensome administrative procedures and around $20 \%$ because they were not meeting the eligibility criteria.

- For workers, two main barriers limit participation in adult learning: the cost of training and the difficulty of combining training and work (Eurostat Adult Education Survey, 2006). Both obstacles are more widespread in Slovakia than on average in the EU and little has been done to address them.

8. In particular, it was funded at $9 \%$ by participants, $10 \%$ by the private sector, and $81 \%$ by the public sector in 2010 (almost 70\% from EU funds). 
- Training provided by public and civic institutions does not concentrate on vocational skills and may not respond to the labour market requirements. VET schools are not involved in adult education ( $1 \%$ of adults in further education were trained by secondary schools). Higher involvement of VET schools into adult education could strengthen the link between VET schools and the labour market as well as remove adult education bottlenecks.

Incentives for employers to allocate more resources and time to training should be enhanced and international benchmarking should be used to reform the public support to lifelong learning. Different forms of financing and incentives for training exist in OECD countries. Compulsory contributions (levy as in France or learning accounts as in Denmark) are quite effective in increasing investment in training but are weighing on the labour cost. Deductions of training costs from the corporate tax base, which are less burdensome for the firms, have also proved to stimulate lifelong learning (OECD, 2005b). Consideration should be given to introduce such tax advantages in Slovakia. Also, income contingent soft loans could be allocated to trainees to avoid credit constraints undermine investment in training. Subsidising lifelong learning will require further monitoring the quality of training provided. The accreditation system of training providers is operational but suppliers are not providing data on their outcomes while it is mandatory according to law (GHK and Research voor Beleid, 2011). Non-complying suppliers should be excluded from future procurement and data collection improved to facilitate the assessment of lifelong learning policies.

Participation of low-qualified and older workers in adult education is low. In particular, the number of training hours of adults with an education level below upper secondary is relatively small by OECD standards. Only $14 \%$ of low-educated engaged in lifelong learning in 2007, 48 percentage points less than adults with tertiary education. The low-educated participating in non-formal education had three times less training hours than the high-educated. Participation of low-qualified and older workers should be supported, because the social gains of improving the productivity and the adaptive capacities of these two groups of workers may exceed private gains. Workers are expected to stay longer in employment and investing more in their human capital should also have an important signalling effect (Bassanini et al., 2005; Chisholm, Burns, 1999). At the same time, for firms, the return of investing in training of low-educated or older workers may be too low and/or lower than for young high skilled (in the case of older workers because of approaching retirement and in the case of low-educated workers because of the need for general education not directly profitable to the firm). This leads to a sub-optimal investment of low-qualified and old-age workers in further education that should be compensated by policy actions. With a few exceptions, public funds for adult learning are not targeted in Slovakia. ${ }^{9}$ Incentives for firms to train low-educated and older workers should be strengthened, as in Austria for instance, where subsidies for trainings depend on the characteristics of recipients and are higher for low-educated (OECD, 2005b).

Box 5. Recommendations for education policy

Improve allocation of funds and increase targeted spending to improve minimum education outcomes

- Remove premiums to eight-year grammar schools as planned and strengthen incentives for the integration of pupils with special needs in the standard system.

- Increase the wages of teachers together with structural measures increasing the efficiency of the system such as consolidating the network of schools, increasing the classroom size and widening the scope for performance-related pay. Encourage sharing of best practices by rewarding collaborative

9. Some initiatives targeted toward youth and financed with EU funds are implemented. For example, the KomPrax project aims to train 15-17 year olds in project management, problem solving, communication, presentation, financial literacy and teamwork. 


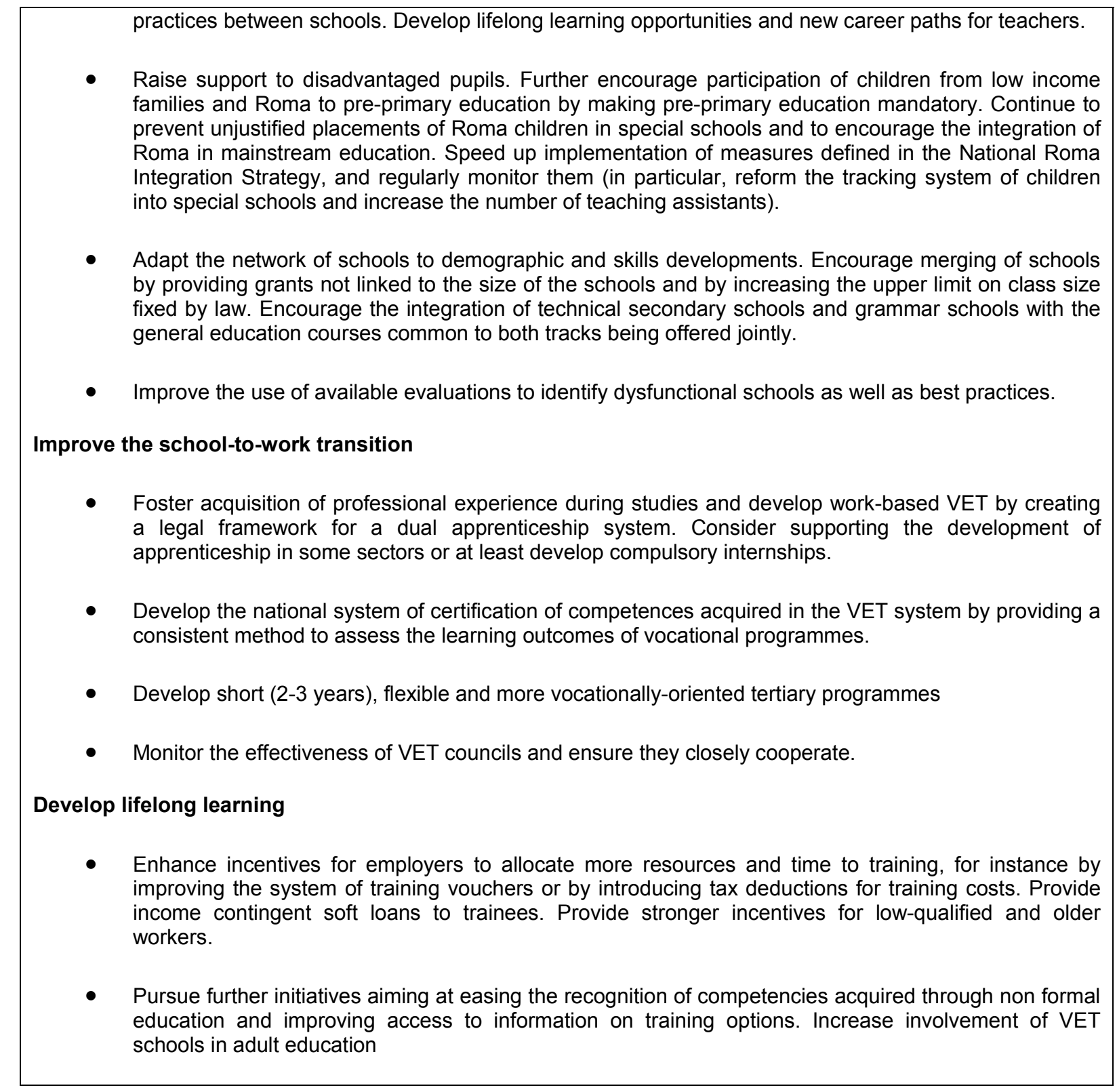




\section{Bibliography}

Afonso, A. and St. Aubyn, M. (2005), "Non-parametric approaches to educational and health expenditures efficiency in OECD countries", Journal of Applied Economics Vol.8(2), pp.227ff.

Afonso, A., Schuknecht, L. and V. Tanzi, (2006), "Public sector efficiency: Evidence for new EU member states and emerging markets", European Central Bank Working Paper, No. 581.

Amnesty International (2010) "Unlock their future; end the segregation of Romani Children in Slovakia's Schools”, Amnesty International, London.

Backes-Gellener, U. and S. Veen (2008), "The Consequences of Central Examinations on Educational Quality Standards and Labour Market Outcomes”, Oxford Review of Education Vol. 34, Issue 5 October 2008, pp. $569-588$.

Bassanini, A. and R. Duval (2006), "Employment Patterns in OECD Countries: Reassessing the Role of Policies and Institutions", OECD Social, Employment and Migration Working Papers, No. 35, OECD Publishing.

Bils, M. and P. Klenow, (2000), “Does Schooling Cause Growth?”, American Economic Review, Vol. 90, pp. $1160-1183$

Bouis, R., R. Duval and F. Murtin (2011), "The Policy and Institutional Drivers of Economic Growth Across OECD and Non-OECD Economies: New Evidence from Growth Regressions", Economics Department Working Papers, No. 843, OECD Publishing.

Boone, J. and J.C. Van Ours (2004), "Effective Active Labour Market Policies", IZA Discussion Papers, No. 1335.

Card, D., Kluve, J., and A. Weber (2009), “Active Labour Market Policy Evaluations: a Meta-analysis”, IZA Discussion Papers, No. 4002.

Carey, D. (2007), "Improving Education Outcomes in the Slovak Republic", Economics Department Working Papers, No. 578, OECD Publishing.

Causa O. and Johansson A., (2009) "Intergenerational Social Mobility," Economics Department Working Papers, No.707, OECD Publishing.

Central labour office (2011) "Implementation of Active Labour Market Policy Tools in 2010", Central Office of Labour, Social Affairs and Family, Bratislava.

Chisholm C.U. and Burns G.R. (1999), "The Role of Work-Based and Workplace Learning in the Development of Life-long Learning for Engineers", Global Journal of Engineering. Educ., Vol. 3, No. 3 
Dar, A. and P. Zafiris Tzannatos (1999), "Active Labor Market Programs: A Review of the Evidence from Evaluations," Social Protection Discussion Paper, No. 9901, The World Bank, Washington, DC.

Duell, N., D. Grubb and S. Singh (2009), "Activation Policies in Finland", OECD Social, Employment and Migration Working Papers, No. 98, OECD Publishing.

Duell, N., P. Tergeist, U. Bazant and S. Cimper (2010a), “Activation Policies in Switzerland”, Social Employment and Migration Working Papers, No. 112, OECD Publishing.

Duell, N., et al. (2010b), "Activation Policies in Japan", OECD Social, Employment and Migration Working Papers, No. 113, OECD Publishing.

European Union Agency for Fundamental Rights (FRA) and United Nations Development Program (UNDP) (2012), "The situation of Roma in 11 EU Member States Survey results at a glance", Publications Office of the European Union.

Friedman, E. and M. Surdu (2009), "School as a ghetto; Systemic overrepresentation of Roma in special education in Slovakia", Roma Education Fund, Paris.

Gonand, F. (2007), "The Impact on Growth of Higher Efficiency of Public Spending on Schools", Economics Department Working Papers, No. 547, OECD Publishing.

Gonand, F., I. Joumard and R. Price (2007), "Public Spending Efficiency: Institutional Indicators in Primary and Secondary Education”, Economics Department Working Papers, No. 543, OECD Publishing.

Grigoli F., (2012), "Public Expenditure in the Slovak Republic: Composition and Technical Efficiency", IMF Working Papers, No. 12/173.

Grubb, D., S. Singh and P. Tergeist (2009), “Activation Policies in Ireland”, Social, Employment and Migration Working Papers, No. 75, OECD Publishing

GHK and Research voor Beleid, (2011), Country report on the Action Plan on Adult Learning: Slovakia.

Handel, M.J. (2012), “Trends in job skill demands in OECD countries”, ELS working papers, forthcoming.

Hanushek, E.A. and L. Woessmann (2009), "Do Better Schools Lead to More Growth? Cognitive Skills, Economic Outcomes, and Causation", NBER Working Papers, No. 14633.

Hanzelova E. and Z. Kostolna (2006), "Služby zamestnanosti v nových podmienkach: Analýza implementačnej praxe”, Rodina Práca a Politika.

Harvan, P. (2010), "Hodnotenie efektivnosti a ucinnosti vydavkov na aktivne politiky trhu prace na Slovensku" (Evaluation of Efficiency and Effectiveness of Spending on Active Labour Market Policies in Slovakia), Economic Analysis, No. 20, Financial Policy Institute at the Ministry of Finance of the Slovak Republic.

Hespel V., Lecerf P.-E., Monnet E., (2011), Étude comparative des effectifs des services publics de l'emploi en France, en Allemagne et au Royaume-Uni, Rapport N² 2010M06402 de l'Inspection générale des finances.

Hoeckel, (2007) "Cost and Benefits in Vocational Education and Training" 
Institute of Information and Prognoses of Education (2011), "The unemployment of secondary school graduates", Institute of Information and Prognoses of Education, Bratislava.

Jacobi, L. and J. Kluve (2006), Before and After the Hartz Reforms: The Performance of Active Labour Market Policy in Germany", IZA Discussion Papers, No. 2100, IZA, Bonn.

Joumard I., P.M. Kongsrud, Y-S. Nam and R. Price (2003), "Enhancing the Effectiveness of Public Spending: Experience in OECD Countries", Economic Studies, No. 37; OECD Publishing.

Kalužná, D. (2008), "Main Features of the Public Employment Service in the Slovak Republic", Social, Employment and Migration Working Papers, No. 72, OECD Publishing.

Kluve, J. (2010), "The effectiveness of European active labour market programs", Labour Economics, 17, Issue 6, p 904-918.

Mc Kinsey (2010) "How the world's most improved school systems keep getting better", Moushed M., Chijioke C. and Barber M., Education, Mc Kinsey and Cie, London.

Marcincin A. and L. Marcincinová (2009), The Cost of Non-Inclusion. The key to integration is respect for diversity, Open Society Foundation, Bratislava.

Martin, J. P. and Grubb, D. (2001), "What Works and for Whom: A Review of OECD Countries' Experiences with Active Labour Market Policies", Swedish Economic Policy Review, Vol. 8, No. 2, pp. 9-56.

Mandl U., Dierx A. and Ilzkovitz F. (2008), "The effectiveness and efficiency of public spending" European Economy Economic Papers, 301, European Commission, Brussels.

Meager N. (2009), "The role of training and skills development in active labour market policies", International Journal of Training and Development, Vol.13 Issue 1, pp 1-18.

Nadazdyova, M. (2011), "Current system of social benefits in Slovakia and proposed reforms", Workshop Proposal and Realisation of Activation Policies, Tulip House, October 11, 2011.

OECD (2005a), "Labour Market Programmes and Activation Strategies: evaluating the impacts", in OECD Employment Outlook 2005, OECD Publishing.

OECD (2005b), Promoting Adult Education, OECD Publishing.

OECD (2007a), Jobs for Youth, The Slovak Republic, OECD Publishing.

OECD (2007b), Economic Survey Slovak Republic, OECD Publishing.

OECD (2007c), Employment Outlook, OECD Publishing.

OECD (2009a), Employment Outlook, OECD Publishing.

OECD (2009b), Economic Survey, Slovak Republic, OECD Publishing.

OECD (2009c), Creating Effective Teaching and Learning Environments: First Results from TALIS,

OECD Publishing. 
OECD (2010a), Off to a Good Start? Jobs for Youth, p19, OECD Publishing.

OECD (2010b), Economic Survey Slovak Republic, OECD Publishing.

OECD (2010c), The High Cost of Low Educational Performance, OECD Publishing.

OECD (2010d), PISA 2009 Results: What Makes a School Successful? Resources, Policies and Practices, Vol. IV, PISA, OECD Publishing.

OECD (2010e), Learning for Jobs, OECD Reviews of Vocational Education and Training, OECD Publishing.

OECD (2010f), Employment Outlook, OECD Publishing.

OECD, (2011a), Education at a Glance, OECD Publishing.

OECD (2011b), The OECD Skills Strategy, Brochure, OECD Publishing.

OECD, (2012a), Employment Outlook, OECD Publishing.

OECD (2012b), “Does Money Buy Strong Performance in PISA?", PISA in Focus, No. 13, OECD Publishing.

OECD (2012c), Economic Survey, Slovak Republic, OECD Publishing.

Paci, P, E. Tiongson, M. Walewski, J. Liwinski, and M. Stoilkova (2007), "Internal Labor Mobility in Central Europe and the Baltic Region", World Bank, Washington, DC.

Psacharopoulos, G. and H.A. Patrinos (2004), "Returns to Investment in Education: A Further Update", Education Economics, Vol. 12, No. 2, pp. 111-134.

Poppe N., Strawn J. and K. Martinson (2003), "Whose Job Is It? Creating Opportunities for Advancement", in Workforce Intermediaries in the $21^{\text {st }}$ Century by Robert P. Giloth (ed.).

Quintini G. (2011), "Right for the Job: Over-qualified or Under-skilled", Social, Employment and Migration Working Papers, No. 120, OECD Publishing.

Šiškovič, M. (2011), "Investovat do vzdelania sa oplati, (Investment in education pays off)", Policy Brief No.2011/2, Financial Policy Institute, Bratislava.

Šiškovič, M. (2012), "Slovenske skolky: malo kapacit a nizsia ucast socialne slabsich rodin, (Slovak preschools: low capacities and lower participation of socially disadvantaged families)", Policy Brief, Financial Policy Institute, Bratislava, forthcoming.

State School Inspection (2011), Report on the status and level of education in schools and school facilities in the Slovak Republic in the academic year 2010/2011, State School Inspection, Bratislava.

Sutherland, D. et al. (2007), "Performance indicators for public spending efficiency in primary and secondary education", Economics Department Working Papers, No. 546, OECD Publishing. 
United Nations Development Programme (2012), Report on the Living Conditions of Roma Households in Slovakia 2010, UNDP Regional Bureau for Europe and the Commonwealth of Independent States, Bratislava, forthcoming.

Vagac, L. (2010) "EEO review: Youth Employment Measures, 2010, Slovakia" Centre for Economic development, European Employment Observatory.

Van Ours, J. C. (2000) "Do Active Labour Market Policies Help Unemployed Workers to Find and Keep Regular Jobs?", IZA Discussion Papers, No. 12.

Venn, D. (2012), "Eligibility Criteria for Unemployment Benefits: Quantitative Indicators for OECD and EU Countries", Social, Employment and Migration Working Papers, No. 131, OECD Publishing.

World Bank (2012a), "Protecting the Poor and Promoting Employability, An assessment of the social assistance system in the Slovak Republic", World Bank, Washington, DC.

World Bank (2012b), "Policy Advice on the Integration of Roma in the Slovak Republic, Overview of Main Findings", World Bank, Washington, DC. 


\section{WORKING PAPERS}

The full series of Economics Department Working Papers can be consulted at www.oecd.org/eco/workingpapers/

1016. The performance of road transport infrastructure and its links to policies (January 2013) by Henrik Braconier, Mauro Pisu and Debra Bloch

1015. The US labour market recovery following the great recession (January 2013) by Wendy Dunn

1014. Why do Russian firms use fixed-term and agency work contracts? (December 2012) by Larisa Smirnykh and Andreas Wörgötter

1013. The Equity implications of fiscal consolidation (December 2012) by Lukasz Rawdanowicz, Eckhard Wurzel and Ane Kathrine Christensen

1012. The Dutch labour market: preparing for the future (December 2012) by Mathijs Gerritsen and Jens Høj

1011. Reforming policies for the business sector to harvest the benefits of globalisation in the Netherlands

(December 2012) by Mathijs Gerritsen and Jens Høj

1010. Health care reform and long-term care in the Netherlands (December 2012) by Erik Schut, Stéphane Sorbe and Jens Høj

1009. Enhancing the inclusiveness of the labour market in Belgium (December 2012) by Jens Høj

1008. Reducing poverty in Estonia through activation and better targeting (December 2012) by Sarah Flèche and Artur Radziwill

1007. Matching skills and jobs in Estonia (December 2012) by Lilas Demmou

1006. Debt and macroeconomic stability: An overview of the literature and some empirics (December 2012) by Douglas Sutherland and Peter Hoeller

1005. Debt and macroeconomic stability: Debt and the business cycle (December 2012) by Volker Ziemann

1004. Debt and macroeconomic stability: Case studies (December 2012) by Rossana Merola

1003. Debt and macroeconomic stability (December 2012) by Douglas Sutherland, Peter Hoeller, Rossana Merola and Volker Ziemann

1002. Reducing greenhouse gas emissions in a cost effective way in Switzerland. (December 2012) by Anita Wölfl and Patrizio Sicari 
1001. Strengthening innovation in the United States

(November 2012) by David Carey, Christopher Hill and Brian Kahin

1000. Long-term growth scenarios

(January 2013) by Åsa Johansson, Yvan Guillemette, Fabrice Murtin, David Turner,

Giuseppe Nicoletti, Christine de la Maisonneuve, Philip Bagnoli, Guillaume Bousquet and

Francesca Spinelli

999. Selected aspects of household savings in Germany - evidence from micro-data

(November 2012) by Christina Kolerus, Isabell Koske and Felix Hüfner

998. Improving the tax system in Indonesia

(November 2012) by Jens Arnold

997. Unleashing business innovation in Canada

(November 2012) by Alexandra Bibbee

996. Public policy and resource allocation: evidence from firms in OECD countries

(October 2012) by Dan Andrews and Federico Cingano

995. Promoting SME development in Indonesia

(October 2012) by Annabelle Mourougane

994. Portugal: Rebalancing the economy and returning to growth through job creation and better capital allocation.

(October 2012) by Álvaro Pina and Ildeberta Abreu

993. Public debt, economic growth and nonlinear effects: Myth or reality?

(October 2012) by Balázs Égert

992. Choosing the pace of fiscal consolidation

(September 2012) by Lukasz Rawdanowicz

991. Tertiary education developing skills for innovation and long-term growth in Canada

(September 2012) by Calista Cheung, Yvan Guillemette and Shahrzad Mobasher-Fard

990. Trade and product market policies in upstream sectors and productivity in downstream sectors:

firm-level evidence from China

(September 2012) by Maria Bas and Orsetta Causa

989. Intangible assets, resource allocation and growth: a framework for analysis

(September 2012) by Dan Andrews and Alain de Serres

988. Current account benchmarks for Turkey

(September 2012) by Oliver Röhn

987. Structural reforms to boost Turkey's long-term growth

(September 2012) by Rauf Gönenç, Oliver Röhn, Vincent Koen and Şeref Saygili

986. Tackling Turkey's external and domestic macroeconomic imbalances

(September 2012) by Oliver Röhn, Rauf Gönenç, Vincent Koen and Ramazan Karaşahin 